\title{
A Study on Use Status and Subsidy Appropriateness of Developmental Rehabilitation Service in Speech- Language Therapy for Disabled Children: Parental Survey
}

\author{
Jaeock Kima, Taewoo Kim ${ }^{\text {, Jo-Young Lee }}{ }^{\mathrm{c}}$, Kyunghee Jung ${ }^{\mathrm{d}}$ \\ ${ }^{a}$ Division of Speech Pathology Education, Graduate School of Education, Kangnam University, Yongin, Korea \\ ${ }^{b}$ Kim's Psychology Language Institute, Incheon, Korea \\ ${ }^{c}$ LEL Language-Psychology-Learning Center, Sangju, Korea \\ ${ }^{d}$ Department of Speech and Language Pathology, Graduate School of Rehabilitation and Welfare, Yong-In University, Yongin, Korea
}

Correspondence: Jaeock Kim, $\mathrm{PhD}$

Division of Speech Pathology Education, Graduate

School of Education, Kangnam University, 40

Gangnam-ro, Giheung-gu, Yongin 16979, Korea

Tel: +82-31-280-3221

Fax: +82-31-280-3479

E-mail: jaeock@gmail.com

Received: October 20, 2018

Revised: November 14, 2018

Accepted: November 19, 2018

This work was supported by funding for the Accreditation Project of the Korean Association of Speech-Language Pathologists (KSLP) on 2018 the Study for Unit Costs of Developmental

Rehabilitation Service.
Objectives: The subsidy of developmental rehabilitation service (voucher) has gone unchanged for more than 10 years without consideration of rising prices or minimum wages, and thus they do not provide high quality rehabilitation services. The purpose of this study was to examine the awareness of the parents of disabled children using vouchers in regards to the use status and subsidy appropriateness of vouchers, in particular, vouchers for speech-language therapy (ST) services. Methods: A questionnaire consisted of 24 questions about the use status and subsidy appropriateness of vouchers and vouchers for ST was distributed to parents of disabled children who were currently using vouchers. Two hundred seventy-six questionnaires were collected and analyzed. Results: Eighty-five percent of the respondents answered that the current subsidy of voucher was not appropriate, with the most frequent response being that KRW 310,000-400,000 would be the appropriate amount. Most children were receiving two types of therapy using vouchers, and the most commonly used type of therapy was ST. The number of ST sessions per month using vouchers was 4 times, however the number of ST session believed to be necessary was 8 times. Seventy-four percent of the respondents said that they paid more than KRW 80,000 in addition to voucher. Conclusion: The developmental rehabilitation service voucher has been provided for the purpose of improving the functioning of disabled children and alleviating the burden of their family, however there is not enough voucher support to achieve t purpose, and it is necessary to increase the amount of voucher subsidy.

Keywords: Developmental rehabilitation service voucher, Subsidy appropriateness, Parental survey
2007년 사회서비스 전자바우처 구축 사업으로 시작된 '노인돌 봄종합서비스, '장애인 활동보조서비스, '지역사회서비스투자사 업'의 세 영역 중 ‘지역사회서비스투자사업'의 한 부분에서 시작된 ‘장애아동재활치료사업'은 2009년부터 성장기 장애아동의 기능향 상과 행동발달을 위한 치료서비스 지원, 정보제공, 장애아동 양육 가정의 경제적 부담 완화라는 목적을 갖고 '지역사회서비스투자사
업'에서 분리하여 독립적인 사업으로 운영되었다(Kim, Kim, \& Kang, 2015). 이 사업은 만 18 세 미만의 뇌병변·지적·자폐성·청각. 언어·시각장애를 가진 등록 장애인과 6세 미만의 장애가 예견되어 재활치료가 필요하다고 인정되는 비장애 등록 아동에게 '언어.청 능, 미술·음악, 행동·놀이·심리, 감각·운동 등'을 제공하는 것으로, 2012년 8월 장애아동복지지원법에 의거하여 ‘발달재활서비스(De- 
Jaeock Kim, et al. • Use Status and Subsidy Appropriateness of Developmental Rehabilitation Service Voucher COMMUNICATION SCIINCES \& DISORDERS

velopment Rehabilitation Service)'라는 새로운 용어로 변경되면서 법적 근거가 마련되었고 보건복지부가 담당을 하고, 지자체에서 운 영을 하고 있다. '발달재활서비스'는 성장기의 정신적.감각적 장애 아동의 기능을 향상시키고 행동발달을 위한 재활치료서비스를 제 공하며, 높은 재활치료 비용으로 인한 장애아동 양육가정의 경제 적 부담을 경감시키는 목적을 갖고 시행되는 바우처(vouchers) 제 도이다(Social Security Information Service, 2015).

국외에서도 장애인을 위한 재활서비스 제공이 국가적 차원 및 비 영리조직 등을 중심으로 이루어지고 있는데, 미국의 경우 발달장 애인 지원 및 권리장전법(Developmental disabilities Assistance and Bill of Rights Act [DD Act], 1975)을 시작으로 발달장애인(인 지적 기능의 제한이 있는 자로 정의하고, 인지장애, 발달장애, 인지/ 발달장애로 표현되는 광범위한 의미)을 위한 정부의 지원이 지속적 으로 이행되고 있다. 연방정부 차원에서 보건복지부(Department of Health and Humans Services, HHS) 산하 인지/발달장애인국 (Administration on Intellectual and Developmental Disabilities, AIDD)을 구성하고 있으며, 연방법 외에 각 주(State)별로 주법 아 래 발달장애인 관련 개별적인 행정조직을 두고 발달장애인에 대한 보다 적극적이고 구체적인 지원을 하고 있다(Hwang, 2016). 미국의 발달장애인들은 주정부의 인지/발달장애인 기관, Medicaid Waiv$\mathrm{er}$, 사회보장(social security)기금, 지역사회 재활서비스 제공기관 등의 다양한 기금으로 서비스를 제공받는데. 특히 일부 주에서는 Medicaid Waiver를 통해 발달장애인의 부모나 보호자의 소득 또 는 재산에 상관없이 서비스를 이용할 수 있기 때문에 국내의 소득 수준을 고려하여 차등적으로 제외하고는 발달재활서비스와는 차 별성이 있다고 할 수 있다(Jeon, 2016).

영국도 장애아동과 그 가족이 적절한 서비스를 지원받는 맞춤형 서비스가 제공되는데, 지원이 필요한 대상자가 의뢰하면 중앙정부
의 '사회서비스국'에서 심사하고 서비스를 결정한 후 지방정부와 계약관계를 맺은 민간기관을 통해 재활서비스를 제공받거나 현금 지원을 받아 개인이 직접 서비스를 구매할 수 있어 정부와 지자체 로부터 민간기관에게 서비스 이용대금이 지불되는 국내와는 일부 다르게 운영되고 있다.

일본의 경우는 2006년부터 시작된 장애인자립지원법을 바탕으 로 장애아동과 청소년(6-18세)의 재활치료 서비스 지원을 위해 발 달지원서비스가 실시되고 있으며, 장애군을 분류하여 특별지원학 교(특수학교)와 특별지원학급에서 구분하여 지원되고 있다.

국내의 발달재활서비스 지원 대상자는 2009년 전국가구 평균소 득 $70 \%$ 이하의 가구에 적용되었으나 2010 년에는 $100 \%, 2013$ 년부 터 $150 \%$ 까지 확대되어 발달재활서비스 이용자의 수는 매년 확대 되고 있다(Kim et al., 2015; Social Security Information Service, 2013, 2015).

발달재활서비스 지원금(급여액)은 최소 14 만 원부터 최대 월 22 만 원으로 소득에 따라 차등 지원되며, 급여액과 본인부담금이 정 해져 있다(Social Security Information Service, 2015). 발달재활서 비스는 시행 초기에 제공되는 치료서비스의 횟수를 월 8회로 규정 함으로써 회당 치료서비스 단가가 27,500원으로 고정되어 있었으 나 최근 시·군·구에 따라 해당지역의 시장가격, 전년도 가격, 타 지 역 가격 등을 고려하여 적정 서비스 단가를 제공기관에 자율적으 로 맡기거나 지자체에서 단가를 책정하는 형태로 변화하였다. 이로 인해 각 기관의 회당 치료단가에 따라 이용자 본인이 추가적으로 부담해야 하는 본인부담금(copayment, 발달재활서비스 총 급여액 [월 22만원]에서 소득 계층에 따라 지원되는 급여액을 뺀 금액)의 비율은 다양하게 적용된다(Figure 1). 시대적 흐름에 따라 변화된 치료단가 체계의 유연성으로 치료단가는 상승된 반면 고정된 22만 원의 지원금에 맞추어 그 범위 내에서만 치료를 받으려는 이용자들

\begin{tabular}{|c|c|c|c|c|c|c|c|}
\hline Income standard & $\begin{array}{l}\text { Total purchas- } \\
\text { ing power }\end{array}$ & \multirow{6}{*}{$=$} & Voucher salary & $\begin{array}{l}\text { Voucher payment per } \\
1 \text { session }\end{array}$ & \multirow{6}{*}{+} & Copayment & $\begin{array}{c}\text { Additional copayment } \\
\text { per } 1 \text { session }\end{array}$ \\
\hline Basic living recipient (Type C) & \multirow{5}{*}{$\begin{array}{l}\text { \#220,000 per } \\
\text { month }\end{array}$} & & *220,000 per month & Session price & & None & None \\
\hline Second tier (Type A) & & & \# 200,000 per month & $91 \%$ of session price & & $\# 20,000$ & 9\% of session price \\
\hline $\begin{array}{l}\text { National household average income } \\
\text { exceeding the next level of } 50 \% \text { or less } \\
\text { (Type B) }\end{array}$ & & & * 180,000 per month & $82 \%$ of session price & & $\# 40,000$ & $18 \%$ of session price \\
\hline $\begin{array}{c}\text { National household average income } \\
\text { exceeding } 50 \% \text { and below } 100 \% \text { (Type D) }\end{array}$ & & & * 160,000 per month & $73 \%$ of session price & & *60,000 & $27 \%$ of session price \\
\hline $\begin{array}{l}\text { National household average income over } \\
\text { 100\% Over 150\% (Type E) }\end{array}$ & & & * 140,000 per month & $64 \%$ of session price & & 80,000 & $36 \%$ of session price \\
\hline
\end{tabular}

Figure 1. Developmental Rehabilitation Service subsidy and copayment rate (source from https://blog.naver.com/haramlets/220937865399). 
의 태도로 인해 치료 횟수는 점차 감소하게 되고, 본인부담금 외에 이용자가 지불해야 하는 본인부담금은 오히려 증가하게 된다. 또한 발달재활서비스의 기준이 되는 월 8회의 치료를 받기 위해서는 이 용자 본인의 자부담으로 추가적인 치료를 받아야 하므로 이용자의 부담은 증가할수밖에 없다.

Kang과 Cho (2014)의 연구에 따르면, 발달재활서비스 회당 치료 단가가 서비스 제공기관의 사정 그리고 지역별, 서비스 내용별로 상 이하고, 서울의 경우에는 각종 재활치료 비용이 기관에 따라 회당 최소 1 만 원부터 최대 4 만 원까지 차이가 있으며, 이로 인해 지정된 지원금 외 장애아동 양육가정이 부담해야 하는 추가 본인부담금 비용이 44만 원에 달하는 곳도 있다고 하였다(Ministry of Health and Welfare, 2010). Kim 등(2015)의 연구에서도 기관방문형 발달 재활서비스 이용단가의 평균 금액은 31,000-34,000원 내외로 발달 재활서비스 초기에 책정된 금액에 비해 최근 증가하였으며, 치료단 가의 범위는 10,000-65,000원으로 넓게 책정되어 있다고 하였다. 이렇듯 발달재활서비스 단가는 시대에 흐름에 따라 상승할 수밖에 없으나 이용자들은 제한된 지원금 내에서만 치료를 받고자 하기 때 문에 치료의 횟수는 감소하게 되거나 이용자가 추가적으로 치료 비 용을 더 부담할 수밖에 없게 된다. Kang, Kim과 Park (2011)의 재활 치료서비스를 제공받는 장애아동을 둔 보호자 333명을 대상으로 심층 면접을 실시한 연구에 따르면, 제한적인 발달재활서비스 지원 금과 추가 비용 문제는 이용 대상자들의 경제적 부담을 증가시키 고, 이로 인해 재활치료 횟수를 감소시키거나 중단하게 되는 경우 가 많아 충분한 재활치료가 이루어지지 못한다고 하였다. 또한 이 용자의 본인부담금이 상승할수록 재활치료서비스의 만족도는 낮 아진다고 하였다(Lee, 2010; Park, 2014).

발달재활서비스는 시작 단계에서 월 8 회를 기준으로 설계된 것 이며, 발달재활서비스 이용자의 부모를 대상으로 치료서비스의 적 정한 주당 평균 이용횟수를 살펴본 선행연구(Kang et al., 2011)에 서도 2 회라고 응답한 비율이 $36.4 \%, 3$ 회는 $31.2 \%$ 로 나타나 주당 $2-3$ 회의 치료서비스가 요구된다는 응답이 전체 응답자의 약 $70 \%$ 를 차지하였다. 즉 장애아동의 재활치료는 최소 주 2 회, 즉 월 8 회 이상은 실시될 필요가 있다. 그러나 앞에서도 언급한 바와 같이 여 러 원인으로 인해 불가피하게 상승할 수밖에 없는 치료단가는 제한 된 지원금 내에서 제공 가능한 치료횟수를 감소시킬 뿐 아니라 가 정에서 추가적으로 지불해야 하는 본인부담금을 증가시키는 결과 를 초래하였다. 이로 인해 결과적으로 발달재활서비스 이용자에게 높은 본인부담금으로 인한 경제적 부담을 가중시키고, 발달재활서 비스 이용자가 원하는 재활치료서비스는 충분히 제공되지 못하는 요인으로 작용하고 있다.
이러한 원인은 10 여 년간 동결된 발달재활서비스 지원금에서 비 롯되었다고 볼 수 있다. 2009년 초기에 책정된 지원금은 물가나 최 저임금 등의 상승을 고려하지 않은 채 10 여 년이 지난 현재까지 동 일하게 유지되고 있어 상승될 수밖에 없는 치료단가에 따른 이용 자의 치료 횟수에 대한 요구 및 질 높은 치료서비스를 제공받고자 하는 요구를 충족시키지 못하고 있는 실정이다.

발달재활서비스 시행 초기와 동일한 금액으로 동결된 낮은 지원 금은 발달재활서비스 치료단가를 기관이나 지자체별로 유연하게 적용할 수 있도록 변화된 정책으로 치료단가가 일정 부분 상승되었 으나 이용자의 본인부담금 증대로 인해 대상자들은 지원금 내에서 만 치료를 시행하려고 하여 치료횟수는 오히려 감소하기 때문에 서 비스수요의 빈도에 따라 임금이 주로 결정되는 발달재활서비스 제 공인력의 근로환경 및 임금체계에도 부정적인 영향을 미친다. 또한 낮은 발달재활서비스 지원금과 더불어 급속도로 증가한 발달재활 서비스 제공기관의 수는 제공기관 간의 심각한 경쟁구도를 형성하 였을 뿐 아니라 제공인력의 신분과 급여의 불안정을 초래하여 이들 의 직무만족도를 경감시켜 왔고, 서비스 제공기관 운영자들의 기관 운영상 수익의 불안정화도 초래하고 있다(Han \& Hwang, 2012; Kang et al., 2011; Kang \& Cho, 2014; Kim, Cho, Park, \& Lee, 2014; Park, Lee, \& Park, 2013). 이는 재활치료서비스의 질을 저하시키는 요인으로 작용하여 장애아동에게 질 높은 재활치료를 제공하고자 하는 발달재활서비스 본래의 취지를 구현하지 못하고 있다.

현행 지급되는 발달재활서비스의 총 지원금(22만 원/월)은 발달 재활서비스를 이용하는 대상자들에게 충분한 재활치료서비스를 제공하기에는 현실적으로 적합하지 않은 금액이며, 한정된 지원금 내에서의 단가조정이라는 미봉책은 발달재활서비스로부터 제공 받는 서비스 비용 외에 추가적으로 소요되는 비용 문제를 유발하 는 요인이 된다. 이제 현 시점에서 발달재활서비스의 적정 지원금에 대한 고민을 해 보아야 할 필요가 있다. Chung과 Seo (2010) 및 Moon (2015)의 연구에서 발달재활서비스 수혜자들이 서비스를 이용하 면서 체감하는 복지시책 개선점으로 치료비 보조금 증가가 가장 필요하다고 지적한 바와 같이 발달재활서비스 이용자의 경제적 부 담을 경감시키고, 제공인력의 처우를 개선시키며, 궁극적으로 재활 치료서비스의 질을 향상시키기 위해서는 회당 서비스 단가의 인상 과 함께 치료 횟수의 증가가 요구된다(Kang et al., 2011; Kang \& Cho, 2014). 이를 위해서는 발달재활서비스 지원금의 인상이 불가 피한 것이다. 이를 위해 발달재활서비스를 이용하는 이용자의 입장 에서 현 발달재활서비스 지원금이 적정한지, 만약 그렇지 않다면 어느 정도가 적정한지 등을 우선적으로 살펴보고 발달재활서비스 지원금 인상의 필요성을 논의해 보아야 할 것이다. 특히 발달재활 
Jaeock Kim, et al. • Use Status and Subsidy Appropriateness of Developmental Rehabilitation Service Voucher COMMUNICATION SCIENCES\& DISORDERS

서비스 이용자들이 가장 많이 선호하고 이용하는 언어치료 영역 (Association of Korea Speech-Language Pathology, 2015; Kang \& Cho, 2014; Kim et al., 2014; Lee, 2009; Lee, 2010; Oh, Yang, \& Jeon, 2009)에 제공되는 발달재활서비스 지원금에 대한 고찰이나 연구 는 그다지 많지 않기 때문에 이에 대해서도 살펴볼 필요가 있다. 이 와 더불어 발달재활서비스를 이용하는 아동의 특성에 따라서도 발달재활서비스의 지원금에 대한 인식, 발달재활서비스 이용 현황 및 언어치료 이용 현황의 차이가 있을 수 있으므로 이에 따른 차이 도 살펴보아야 할 것이다.

이에 본 연구는 발달재활서비스를 이용하는 아동의 부모를 대상 으로 국내 발달재활서비스의 지원금에 대한 인식, 발달재활서비스 이용 현황, 특히 언어치료서비스의 이용 현황을 조사하고, 이를 바 탕으로 발달재활서비스의 지원금의 인상이 필요한지에 대해 살펴 보고자 하였다.

본 연구의 연구문제는 다음과같다.

1) 발달재활서비스를 이용하는 아동 부모의 발달재활서비스 지 원금에 대한 인식은 어떠한가?

2) 발달재활서비스를 이용하는 아동의 발달재활서비스 이용 현 황은 어떠한가?

3) 발달재활서비스를 이용하는 아동의 언어치료 발달재활서비 스 이용 현황은 어떠한가?

4) 발달재활서비스를 이용하는 아동의 특성에 따른 부모의 발달 재활서비스 지원금에 대한 인식, 발달재활서비스 이용 현황 및 언어치료 발달재활서비스 이용 현황의 차이가 있는가?

\section{연구 방법}

\section{조사 도구}

국내 발달재활서비스를 이용하고 있는 아동의 부모를 대상으로 발달재활서비스 지원금에 대한 인식을 포함한 발달재활서비스 이
용 현황 및 언어치료 발달재활서비스 이용 현황에 관한 설문조사 를 위해 학계 및 현장 전문가의 자문 및 기존의 선행연구들(Chung \& Seo, 2010; Kim et al., 2014; Kim \& Hwang, 2013)을 토대로 연구 진들은 수 차례 회의를 하였다. 회의결과를 통해 '인구사회학적 특 성’ 5문항, ‘발달재활서비스 아동 특성' 4문항, ‘발달재활서비스 지 원금 인식' 2문항, ‘발달재활서비스 이용 현황' 4 문항, '언어치료 발 달재활서비스 이용 현황 8 문항의 총 23 개 문항으로 구성된 예비 설문지를 제작하였다.

설문지의 타당도는 발달재활서비스를 제공한 경험이 있거나 현 재 제공하고 있는 전문가 5 명(사설치료기관 원장 4 명과 교수 1 명)에 게 각 문항별로 내용타당도를 5점 척도(1점 매우 타당하지 않음-5점 매우 타당함)로 두 차례에 걸쳐 평가하도록 하였다. 내용타당도를 실시한 전문가들에 대한 정보는 Table 1과 같다. 1 차 내용타당도 결 과는 4.75점이었고, 검토된 내용을 바탕으로 일부 문항을 수정하고 '발달재활서비스 아동' 영역에 1 문항을 추가하여 작성된 설문지에 대한 2차 내용타당도 결과는 4.90점이었다. 이를 바탕으로 문항들 을 수정하여 ‘인구사회학적 특성' 5문항, '발달재활서비스 아동 특 성' 5문항, ‘발달재활서비스 지원금 인식' 2문항, ‘발달재활서비스 이 용 현황' 4 문항, '언어치료 발달재활서비스 이용 현황' 8 문항의 총 24 문항으로 구성된 최종 설문지가 제작되었다(Table 2, Appendix 1).

Table 1. Expert information performing content validity of the survey

\begin{tabular}{ccccccc}
\hline $\begin{array}{c}\text { Age (yr)/ } \\
\text { Sex }\end{array}$ & Education & Job & $\begin{array}{c}\text { Work } \\
\text { place }\end{array}$ & $\begin{array}{c}\text { Clinical } \\
\text { career (yr) }\end{array}$ & $\begin{array}{c}\text { Voucher } \\
\text { period (yr) }\end{array}$ \\
\hline 1 & $42 / \mathrm{M}$ & $\begin{array}{c}\text { Completion of } \\
\text { doctoral course }\end{array}$ & SLP & Kangwon & 17 & 9 \\
2 & $43 / \mathrm{F}$ & Master's degree & SLP & Kyungbuk & 18 & 8 \\
3 & $58 / \mathrm{F}$ & Master's degree & SLP & Gwangju & 19 & 10 \\
4 & $47 / \mathrm{F}$ & PhD & Professor & Gyeonggi & 26 & 10 \\
5 & $45 / \mathrm{M}$ & $\begin{array}{c}\text { Completion of } \\
\text { doctoral course }\end{array}$ & SLP & Seoul & 20 & 10 \\
\hline
\end{tabular}

$S L P=$ speech-language pathology

Table 2. Questionnaire for the survey on use status of Developmental Rehabilitation Service voucher

\begin{tabular}{|c|c|c|}
\hline Area & $\begin{array}{c}\text { Number of } \\
\text { question }\end{array}$ & Contents \\
\hline Demographic characteristics & 5 & Sex, age, education, residence, number of children \\
\hline Characteristics of children using voucher & 5 & Age, status of diagnosis for disorder, diagnosis, type of problem, period using voucher \\
\hline Awareness of voucher subsidy & 2 & Appropriateness of current subsidy, appropriate subsidy \\
\hline Use status of voucher & 4 & $\begin{array}{l}\text { Number of therapy, type of therapy most needed, type of therapy currently receiving (1st-line therapy, 2nd-line } \\
\text { therapy) }\end{array}$ \\
\hline Use status of speech-language therapy voucher & 8 & $\begin{array}{l}\text { Usage, number of therapy per month, appropriate number of therapy per month, copayment, appropriateness } \\
\text { of copayment, number of therapy session for additional copayment, additional copayment, need for support- } \\
\text { ing disabled adults }\end{array}$ \\
\hline
\end{tabular}




\section{자료 수집}

서울, 경기(의정부, 의왕), 인천, 경북(대구), 경남(부산), 전북(익 산), 강원(원주)의 7 개 지역의 언어치료 및 다양한 재활치료서비스 를 제공하고 있으며 Table 3에 제시된 바와 같이 치료실을 운영한 기간이 최소 5 년 이상(평균 13.20 년), 발달재활서비스를 제공한 기 간이 최소 5년 이상(평균 7.50년), 그리고 각 기관에서 발달재활서 비스를 이용하는 아동이 최소 10 명 이상(평균 74.50 명)인 10 개의 사설치료실에서 발달재활서비스를 이용하는 아동의 부모를 대상 으로 우편을 이용하여 360 부의 설문지를 배부하였다. 설문기간은 2018년 7월 20일부터 9월 7일까지 약 7주간 실시하였고, 회수된 부 수는 총 294부로 회수율은 $81.7 \%$ 였으며, 이 중 설문이 미완료되었 거나불성실하게 응답된 18 부를 제외한 276 부를 분석하였다.

\section{자료 분석}

본 연구는 설문지의 각 문항을 점수화하여 통계처리하였고, 수 집된 모든 자료는 SPSS 24.0 (SPSS Inc., Chicago, IL, USA)을 사용 하여 분석하였다. 각 문항의 수준을 살펴보기 위하여 기술통계를 이용하여 빈도, 백분율, 평균 및 표준편차 등을 산출하였다. 단, 각 문항에서 미응답인 경우는 백분율 산출에서 제외시켰다.

또한 발달재활서비스 아동 특성(연령, 장애진단명, 문제 유형, 발 달재활서비스 이용기간)에 따른 발달재활서비스 지원금 인식(현 지 원금 적정성, 적정 지원금), 발달재활서비스 이용 현황(치료 개수, 가장 필요한 치료 유형, 현 1순위 및 2순위 치료 유형) 및 언어치료 발달재활서비스 이용 현황(이용 여부, 월평균 치료 횟수, 적정 월평 균 치료 횟수, 본인부담금, 본인부담금 적정성, 본인부담금 외 자비 부담 치료 횟수, 자비부담 비용)의 차이를 살펴보기 위해 카이제곱

Table 3. Information of institution participating in the study

\begin{tabular}{llcccc}
\hline Location & $\begin{array}{c}\text { Institution } \\
\text { service } \\
\text { period (yr) }\end{array}$ & $\begin{array}{c}\text { Voucher } \\
\text { period } \\
\text { (yr) }\end{array}$ & $\begin{array}{c}\text { Session price } \\
\text { of ST } \\
\text { (KRW) }\end{array}$ & $\begin{array}{c}\text { Number of } \\
\text { children using } \\
\text { voucher }\end{array}$ \\
\hline 1 & Kyungbuk & 7 & 6 & 35,000 & 60 \\
2 & Kyungbuk & 19 & 9 & 35,000 & 32 \\
3 & Kyungbuk & 9 & 7 & 35,000 & 10 \\
4 & Gyeongnam & 20 & 9 & 32,500 & 55 \\
5 & Incheon & 20 & 9 & 40,000 & 80 \\
6 & Gyeonggi & 17 & 9 & 44,000 & 78 \\
7 & Gyeonggi & 8 & 6 & 40,000 & 68 \\
8 & Seoul & 19 & 9 & 44,000 & 195 \\
9 & Gangwon & 5 & 4 & 40,000 & 77 \\
10 & Jeonbuk & 9 & 7 & 32,000 & 90 \\
\multicolumn{7}{l}{\begin{tabular}{l} 
M SD \\
\hline
\end{tabular}}
\end{tabular}

$\mathrm{ST}=$ speech-language therapy; KRW= Korean won.
검정 $\left(\chi^{2}\right.$ test $)$ 을 실시하였다.

\section{연구 결과}

\section{인구사회학적 특성}

발달재활서비스를 이용하는 아동의 부모에게 발달재활서비스 지원금에 대한 인식 및 발달재활서비스 이용 현황 그리고 언어치료 발달재활서비스 이용 현황을 조사하기 위해 실시한 설문에 응답한 응답자의 인구사회학적 특성은 Table 4 와 같다. 성별은 276 명 중 여 성(88.4\%)이 남성(11.6\%)에 비해 많았고, 연령은 40-49세가 $46.7 \%$ 로 가장 많았으며, 그 다음으로 30-39세(40.1\%), 50-59세(9.1\%), 20-29세(2.2\%), 60세 이상(1.8\%)의 순으로 나타났다. 학력은 대졸

Table 4. Demographic characteristics of respondents

\begin{tabular}{lc}
\hline Characteristic & $\mathrm{N}(\%)$ \\
\hline Gender & \\
Men & $32(11.6)$ \\
Women & $244(88.4)$ \\
Total & $276(100)$ \\
Age (yr) & \\
$20-29$ & $6(2.2)$ \\
$30-39$ & $110(40.1)$ \\
$40-49$ & $128(46.7)$ \\
$50-59$ & $25(9.1)$ \\
$\geq 60$ & $5(1.8)$ \\
Total & $27(100)$ \\
Education & \\
Less than high school graduate & $84(30.4)$ \\
Associate & $78(28.3)$ \\
Bachelor & $97(35.1)$ \\
More than Master & $17(6.2)$ \\
Total & $276(100)$ \\
Residence & $275(100)$ \\
Seoul & $26(9.4)$ \\
Incheon-Gyeonggi & $125(45.3)$ \\
Gwangju-Jeolla & $29(10.5)$ \\
Daegu-Kyungbuk & $58(21.0)$ \\
Busan-Ulsan-Gyeongnam & $17(6.2)$ \\
Gangwon & $21(7.6)$ \\
Total & $276(100)$ \\
Number of children & \\
1 & $80(29.1)$ \\
2 & $157(57.1)$ \\
3 & $28(10.2)$ \\
Total & $8(2.9)$ \\
\hline & \\
\hline & \\
\hline & \\
\hline
\end{tabular}


Jaeock Kim, et al. • Use Status and Subsidy Appropriateness of Developmental Rehabilitation Service Voucher

(35.1\%), 고졸 이하(30.4\%), 전문학사(28.3\%), 대학원 이상(6.2\%)의 순이었다. 응답자의 거주지는 인천-경기가 $45.3 \%$ 로 가장 많았고, 대구-경북(21.0\%), 광주-전라(10.5\%), 서울(9.4\%), 강원(7.6\%), 부 산-울산-경남(6.2\%)이었다. 응답자의 자녀 수는 2명(57.1\%)이라고 응답한 경우가 가장 많았고, 그 다음은 1 명(29.1\%), 3명(10.2\%), 4명 (2.9\%), 5 명(.7\%)의 순이었다.

\section{발달재활서비스 이용 아동 특성}

발달재활서비스를 이용하는 아동의 특성을 살펴본 결과(Table $5)$, 아동 연령의 평균(표준편차)은 8.16 (4.35)세로 1-18세의 다양한 연령대가 분포하였으며, 1-5세는 104명(37.8\%), 6-12세는 116명 (42.2\%), 13-18세는 55명(20.0\%)이었다. 아동의 장애진단 여부에 대 한 응답으로는 ‘예'가 $74.2 \%$, ‘아니오'가 $25.8 \%$ 였다. 중복으로 응답

Table 5. Characteristics of children using Development Rehabilitation Services (voucher)

\begin{tabular}{lc}
\hline Characteristic & $\mathrm{N}(\%)$ \\
\hline Status of diagnosis for disorder & \\
Yes & $204(74.2)$ \\
No & $71(25.8)$ \\
Total & $275(100)$ \\
Diagnosis (duplicate response possible) & \\
Autistic disorder & $38(16.5)$ \\
Intellectual disability & $98(42.6)$ \\
Communication disorder & $33(14.3)$ \\
Hearing impairment & $8(3.5)$ \\
Brain disorder & $46(20.0)$ \\
Others & $7(3.0)$ \\
Total & $230(100)$ \\
Type of problem (duplicate response possible) & \\
Communication & $186(49.2)$ \\
Sociability & $67(17.7)$ \\
Intellectual & $73(19.3)$ \\
Hearing & $4(1.1)$ \\
Motor skill & $41(10.8)$ \\
Others & $7(1.9)$ \\
Total & $378(100)$ \\
Period using voucher (yr) & \\
$<1$ & $51(18.5)$ \\
$<1-2$ & $45(16.4)$ \\
$<2-3$ & $38(13.8)$ \\
$<3-4$ & $27(9.8)$ \\
$<4-5$ & $34(12.4)$ \\
$<5-6$ & $19(6.9)$ \\
$<6-7$ & $18(6.5)$ \\
$\geq 7$ & $43(15.6)$ \\
Total & $275(100)$ \\
\hline
\end{tabular}

가능한 문항인 아동의 장애진단명은 지적장애(42.6\%)가 가장 많 았고, 그 다음으로 뇌병변장애(20.0\%), 자폐성장애(16.5\%), 언어장 애(14.3\%), 청각장애(3.5\%), 기타(3.0\%)로 나타났으며, 주로 나타나 는 어려움(문제 유형)으로는 의사소통(49.2\%)이 절반 이상의 비율 을 보였고, 그 다음으로 인지(19.3\%), 사회성(17.7\%), 운동능력 (10.8\%), 기타(1.9\%), 청력(1.1\%)의 순이었다. 아동의 발달재활서비 스 이용기간은 1 년 미만(18.5\%)이 가장 많았고, 6-7년(6.5\%)이 가장 적었으며, 이를 재분류하여 살펴보면 1-3년 미만이 83명(30.2\%), 5 년 이상이 80명(29.1\%), 3-5년 미만이 61명(22.2\%), 1년 미만이 51명 $(18.5 \%)$ 이었다.

\section{발달재활서비스 지원금 인식}

발달재활서비스 지원금 인식에 대한 응답의 분석 결과(Table 6), 현재 발달재활서비스 지원금(22만 원/월)의 적정성 여부에 '예’라고 응답한 경우는 $15.9 \%$ 인 반면, ‘아니오'는 $84.1 \%$ 였고, 적정 지원금은

Table 6. Parent's awareness of Developmental Rehabilitation Service voucher

\begin{tabular}{lr}
\hline Question & $\mathrm{N}(\%)$ \\
\hline Appropriateness of current subsidy & \\
Yes & $44(15.9)$ \\
No & $232(84.1)$ \\
Total & $276(100)$ \\
Appropriate subsidy (KRW) & \\
Current level & $31(11.2)$ \\
$230,000-300,000$ & $80(29.0)$ \\
$310,000-400,000$ & $100(36.2)$ \\
$410,000-500,000$ & $38(13.8)$ \\
$\geq 510,000$ & $27(9.8)$ \\
Total & $276(100)$ \\
\hline
\end{tabular}

$\mathrm{KRW}=$ Korean won.

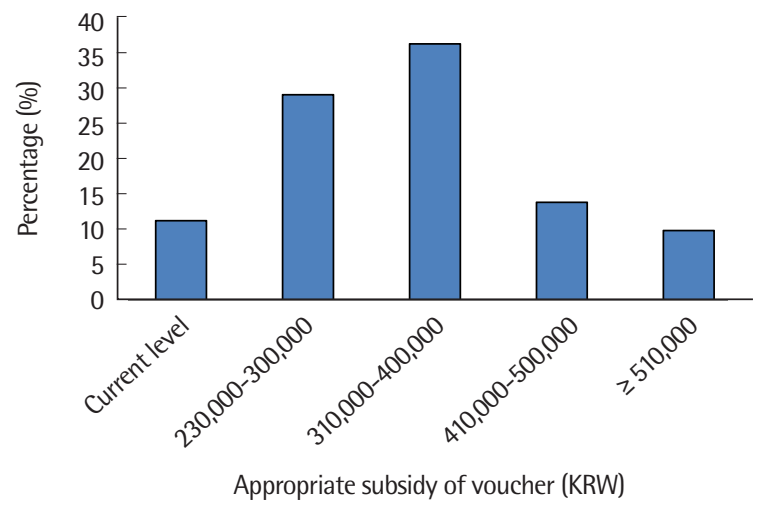

Figure 2. Appropriate subsidy of Developmental Rehabilitation Service voucher. $\mathrm{KRW}=$ Korean won. 
31-40만 원(36.2\%)이라고 응답한 경우가 가장 많았으며, 23-30만 원(29.0\%), 41-50만 원(13.8\%), 현재 수준 정도(11.2\%), 51만 원 이상 (9.8\%)의 순으로 나타났다(Figure 2).

\section{발달재활서비스 이용 현황}

발달재활서비스 이용 현황에 대한 문항들을 분석한 결과는 Table 7과 같다. 현재 아동이 제공받는 전체 치료 프로그램 개수는 2 개(42.2\%)는 응답이 가장 많았고, 1 개(26.5\%), 3개(19.6\%), 4 개 이상 (11.6\%)의 순이었다. 아동에게 가장 필요한 치료 유형은 언어치료

Table 7. Use status of Developmental Rehabilitation Service voucher

\begin{tabular}{|c|c|}
\hline Question & $\mathrm{N}(\%)$ \\
\hline \multicolumn{2}{|l|}{ Number of therapy } \\
\hline 1 & $73(26.5)$ \\
\hline 2 & $116(42.2)$ \\
\hline 3 & $54(19.6)$ \\
\hline$\geq 4$ & $32(11.6)$ \\
\hline Total & $275(100)$ \\
\hline \multicolumn{2}{|l|}{ Type of therapy most needed } \\
\hline Speech-language & $150(54.3)$ \\
\hline Intellectual/learning/behavior & $68(24.6)$ \\
\hline Play & $7(2.5)$ \\
\hline Sensory integration & $1(5.8)$ \\
\hline Art & $3(1.1)$ \\
\hline Music & $1(.4)$ \\
\hline Psychology/counseling & $13(4.7)$ \\
\hline Others & $18(6.5)$ \\
\hline Total & $276(100)$ \\
\hline \multicolumn{2}{|l|}{ 1st-line therapy } \\
\hline Speech-language & $173(62.9)$ \\
\hline Intellectual/learning/behavior & $46(16.7)$ \\
\hline Play & $8(2.9)$ \\
\hline Sensory integration & $16(5.8)$ \\
\hline Art & $4(1.5)$ \\
\hline Music & $0(0)$ \\
\hline Psychology/counseling & $6(2.2)$ \\
\hline Others & $22(8.0)$ \\
\hline Total & $275(100)$ \\
\hline \multicolumn{2}{|l|}{ 2nd-line therapy } \\
\hline Speech-language & $57(22.4)$ \\
\hline Intellectual/learning/behavior & $76(29.9)$ \\
\hline Play & $38(15.0)$ \\
\hline Sensory integration & $30(11.8)$ \\
\hline Art & $10(3.9)$ \\
\hline Music & $13(5.1)$ \\
\hline Psychology/counseling & $18(7.1)$ \\
\hline Others & $12(4.7)$ \\
\hline Total & $254(100)$ \\
\hline
\end{tabular}

Table 8. Use status of speech-language therapy Developmental Rehabilitation Service voucher

\begin{tabular}{|c|c|}
\hline Question & $\mathrm{N}(\%)$ \\
\hline \multicolumn{2}{|l|}{ Usage } \\
\hline Yes & $231(83.7)$ \\
\hline No & $45(16.3)$ \\
\hline Total & $276(100)$ \\
\hline \multicolumn{2}{|c|}{ Number of therapy per month } \\
\hline$<4$ & $33(12.1)$ \\
\hline 4 & $104(38.1)$ \\
\hline 5 & $28(10.3)$ \\
\hline 6 & $44(16.1)$ \\
\hline 7 & $8(2.9)$ \\
\hline 8 & $46(16.8)$ \\
\hline$\geq 9$ & $10(3.7)$ \\
\hline Total & $273(100)$ \\
\hline \multicolumn{2}{|c|}{ Appropriate number of therapy per month } \\
\hline$<4$ & $11(4.1)$ \\
\hline 4 & $33(12.2)$ \\
\hline 5 & $8(3.0)$ \\
\hline 6 & $36(13.3)$ \\
\hline 7 & $7(2.6)$ \\
\hline 8 & $129(47.6)$ \\
\hline$\geq 9$ & 47 (17.3) \\
\hline Total & $271(100)$ \\
\hline \multicolumn{2}{|l|}{ Copayment (KRW) } \\
\hline None & $35(13.3)$ \\
\hline 20,000 & $27(10.3)$ \\
\hline 40,000 & $69(26.2)$ \\
\hline 60,000 & $71(27.0)$ \\
\hline 80,000 & $61(23.2)$ \\
\hline Total & $263(100)$ \\
\hline \multicolumn{2}{|c|}{ Appropriateness of copayment } \\
\hline Yes & $73(26.7)$ \\
\hline No & 200 (73.3) \\
\hline Total & $273(100)$ \\
\hline \multicolumn{2}{|c|}{ Number of therapy session for additional copayment } \\
\hline None & $82(30.1)$ \\
\hline 1 & $20(7.4)$ \\
\hline 2 & $39(14.3)$ \\
\hline 3 & $24(8.8)$ \\
\hline 4 & $62(22.8)$ \\
\hline$\geq 5$ & $4(16.5)$ \\
\hline Total & $272(100)$ \\
\hline \multicolumn{2}{|c|}{ Additional copayment (KRW) } \\
\hline None & $34(12.5)$ \\
\hline$\leq 40,000$ & $38(14.0)$ \\
\hline $41,000-80,000$ & $43(15.8)$ \\
\hline $81,000-120,000$ & $41(15.1)$ \\
\hline $121,000-160,000$ & $37(13.6)$ \\
\hline $161,000-200,000$ & $28(10.3)$ \\
\hline$\geq 210,000$ & $51(18.8)$ \\
\hline Total & $272(100)$ \\
\hline \multicolumn{2}{|c|}{ Need for supporting disabled adults } \\
\hline Yes & $258(93.8)$ \\
\hline No & $17(6.2)$ \\
\hline Total & $275(100)$ \\
\hline
\end{tabular}

KRW = Korean won. 
Jaeock Kim, et al. • Use Status and Subsidy Appropriateness of Developmental Rehabilitation Service Voucher COMMUNICATION SCIINCES\& DISORDERS

(54.3\%), 인지/학습/행동치료(24.6\%), 기타(운동치료, 특수체육 등; $6.5 \%)$, 감각통합치료(5.8\%), 심리/상담치료(4.7\%), 놀이치료(2.5\%), 미술치료(1.1\%), 음악치료(.4\%)의 순이었다. 현재 아동이 제공받고 있는 1순위 치료 프로그램은 언어치료(62.9\%), 인지/학습/행동치 료(16.7\%), 기타(8.0\%), 감각통합(5.8\%), 놀이치료(2.9\%), 심리/상담 치료(2.2\%), 미술치료(1.5\%)였으며, 음악치료라고 응답한 경우는 없었다. 현재 아동이 제공받고 있는 2순위 치료 프로그램으로는 인 지/학습/행동치료(29.9\%), 언어치료(22.4\%), 놀이치료(15.0\%), 감각 통합(11.8\%), 심리/상담치료(7.1\%), 음악치료(5.1\%), 기타(4.7\%), 미 술치료(3.9\%)의 순이었다(Figure 3).

\section{언어치료 발달재활서비스 이용 현황}

발달재활서비스로 언어치료를 이용하는 현황에 대한 문항들에 응답한 결과는 Table 8에 제시하였다. 아동의 발달재활서비스로 언 어치료 이용 여부는 '예’가 $83.7 \%$, '아니오'가 $16.3 \%$ 로 대부분이 발 달재활서비스를 이용하여 언어치료를 제공받고 있음을 알 수 있다. 발달재활서비스 이용 월평균 언어치료 횟수는 4회(38.1\%), 8회(16.8\%), 6회(16.1\%), 4회 미만(12.1\%), 5회(10.3\%), 9회 이상(3.7\%), 7회(2.9\%) 의 순이었고, 발달재활서비스 이용 월평균 언어치료 적정 횟수는 8 회(47.6\%), 9회 이상(17.3\%), 6회(13.3\%), 4회(12.2\%), 4회 미만(4.1\%), 5 회(3.0\%), 7회(2.6\%)의 순으로 나타났다(Figure 4). 즉 발달재활서 비스 이용 아동의 부모나 보호자가 적정하다고 인식하는 월평균 언 어치료 횟수는 8 회가 가장 많은 반면 실제 이용하고 있는 월평균 언 어치료 횟수는 4 회가 가장 많았다. 또한 소득수준에 따라 발달재 활서비스로 언어치료를 이용할 때 지불해야 하는 본인부담금으로 는 6만 원, 4 만 원, 8 만 원이 각 $27.0 \%, 26.2 \%, 23.2 \%$ 를 차지하였고,
면제되거나 2 만 원인 경우가 각 $13.3 \%, 10.3 \%$ 였다. 본인부담금의 적 정성 여부에 대한 질문에 ‘아니오’라고 응답한 경우가 $73.3 \%$ 였고, ‘예’는 $26.7 \%$ 였다. 발달재활서비스 지원금 외 자비로 추가 부담하는 월평균 언어치료 횟수는 없음(30.1\%), 4회(22.8\%), 5회 이상(16.5\%), 2회(14.3\%), 3회(8.8\%), 1회(7.4\%)였고, 추가 자비부담금은 210,000 원 이상이 $18.8 \%$ 로 가장 높은 비율을 차지하였으며, $41,000-80,000$ 원과 $81,000-120,000$ 원이 각 $15.8 \%$ 와 $15.1 \%, 40,000$ 원 이하가 $14.0 \%$, $121,000-160,000$ 원과 $161,000-200,000$ 원이 각 $13.6 \%$ 와 $10.3 \%$ 였으 며, 부담하지 않음이 $12.5 \%$ 였다.

아동이 성인이 된 후에도 지원금이 필요한지에 대한 문항에 '예' 라고 응답한 경우가 $93.8 \%$ 였고, '아니오'가 6.2\%로 발달재활서비스 를 이용하는 장애아동 부모들의 대부분이 자녀들이 성인이 되어서 도 지속적으로 치료서비스를 제공받을 수 있는 정부로부터의 지원

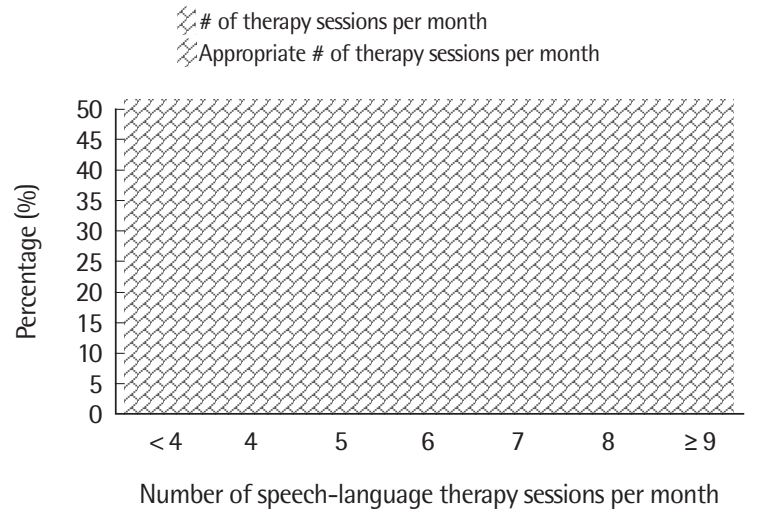

Figure 4. Number of speech-language therapy (ST) sessions per month and appropriate number of ST per month using Developmental Rehabilitation Service voucher.

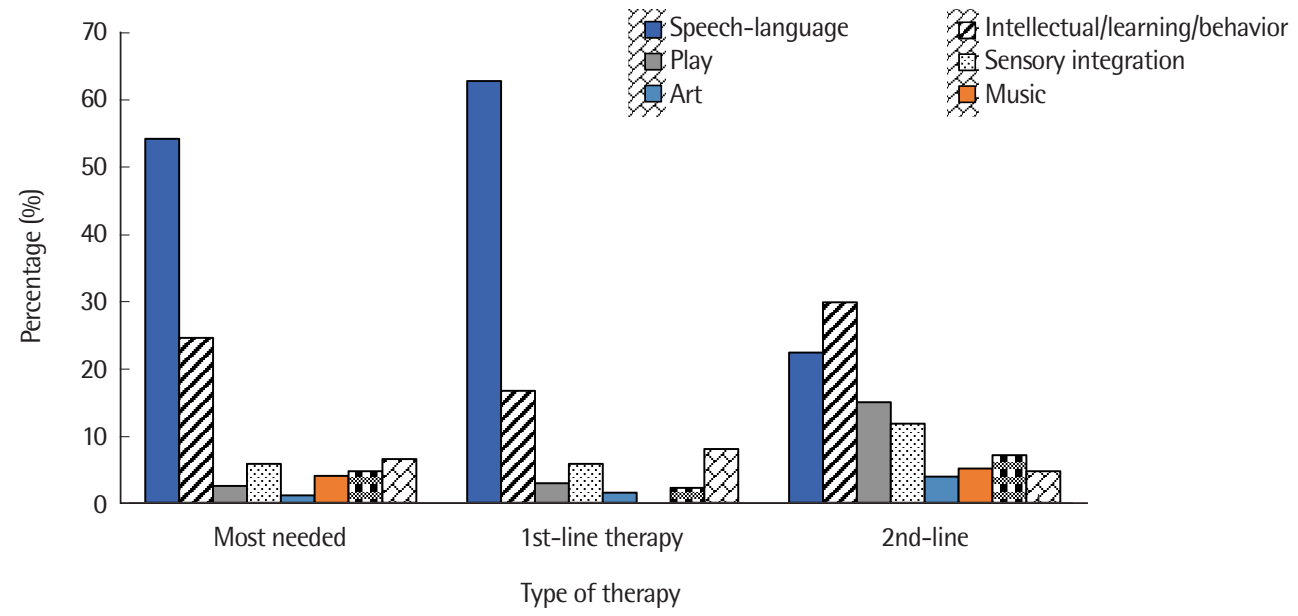

Figure 3. Type of therapy most needed and currently receiving (1st-line therapy and 2nd-line therapy) using Developmental Rehabilitation Service voucher. 
금이 필요하다고 하였다.

\section{발달재활서비스 이용 아동의 연령에 따른 차이}

발달재활서비스를 이용하는 아동의 연령에 따른 각 변수들의 차 이를 분석하기 위해 아동의 연령을 학령전기 1-5세, 초등학령기인 6-12세, 청소년기인 13-18세로 구분하였다.

발달재활서비스를 이용하는 아동 중 1-5세에서 장애진단을 받은 경우는 42.3\%로 그렇지 않은 57.7\%보다 적은 반면, 6-12세와 13-18 세는 장애진단을 받은 경우가 각 $90.5 \%$ 와 $100.0 \%\left(\chi^{2}=90.472, p<\right.$ .001)였다(Table 9).

발달재활서비스를 이용하는 아동의 연령별 진단명은 Table 10 과 같이 1-5세의 경우 뇌병변장애가 $34.0 \%$ 로 가장 많은 반면, 6-12 세와 $13-18$ 세는 지적장애가 각 $51.9 \%$ 와 $61.8 \%$ 로 가장 많아 연령이

Table 9. Differences in status of diagnosis for disorder by children's age

\begin{tabular}{lccc}
\hline \multirow{2}{*}{$\begin{array}{c}\text { Status of diagnosis for } \\
\text { disorder }\end{array}$} & \multicolumn{3}{c}{ Age group (yr) } \\
\cline { 2 - 4 } & $1-5$ & $6-12$ & $13-18$ \\
\hline Yes & $44(42.3)$ & $105(90.5)$ & $55(100)$ \\
No & $60(57.7)$ & $11(9.5)$ & $0(0)$ \\
Total & 104 & 116 & 55 \\
\hline
\end{tabular}

Values are presented as number $(\%)$.

Table 10. Differences in name of diagnosis by children's age

\begin{tabular}{lccc}
\hline \multirow{2}{*}{ Diagnosis } & \multicolumn{3}{c}{ Age group (yr) } \\
\cline { 2 - 4 } & $1-5$ & $6-12$ & $13-18$ \\
\hline Autistic disorder & $6(12.0)$ & $22(20.8)$ & $10(18.0)$ \\
Intellectual disability & $6(12.0)$ & $55(51.9)$ & $34(61.8)$ \\
Communication disorder & $13(26.0)$ & $8(7.5)$ & $1(1.8)$ \\
Hearing impairment & $4(8.0)$ & $3(2.8)$ & $0(0)$ \\
Brain disorder & $17(34.0)$ & $17(16.0)$ & $9(16.4)$ \\
Others & $4(8.0)$ & $1(.9)$ & $1(1.8)$ \\
Total & 50 & 106 & 55
\end{tabular}

Values are presented as number (\%).

Table 11. Differences in type of problem by children's age

\begin{tabular}{lccc}
\hline \multirow{3}{*}{ Type of problem } & \multicolumn{3}{c}{ Age group (yr) } \\
\cline { 2 - 4 } & $1-5$ & $6-12$ & $13-18$ \\
\hline Communication & $75(72.1)$ & $68(58.6)$ & $22(40.0)$ \\
Sociability & $6(5.8)$ & $17(14.7)$ & $11(20.0)$ \\
Intellectual & $8(7.7)$ & $17(14.7)$ & $16(29.1)$ \\
Hearing & $2(1.9)$ & $0(0)$ & $0(0)$ \\
Motor skill & $13(12.5)$ & $12(10.3)$ & $6(10.9)$ \\
Others & $0(0)$ & $2(1.7)$ & $0(0)$ \\
Total & 104 & 116 & 55 \\
\hline
\end{tabular}

Values are presented as number (\%).
증가할수록 지적장애로 진단받은 경우가 더 많았다 $\left(\chi^{2}=39.275\right.$, $p<.001)$.

발달재활서비스를 이용하는 아동의 연령에 따른 문제 유형은 Table 11과 같이 모든 연령대에서 의사소통 문제가 가장 높은 비율 을 차지하였으나(1-5세 72.1\%, 6-12세 58.6\%, 13-18세 40.0\%) 그 다 음으로 많은 문제 유형은 1-5세에서는 운동능력이 12.5\%, 6-12세 와 $13-18$ 세에서 인지가 각 $14.7 \%$ 와 $29.1 \%$ 로 연령이 증가할수록 인 지 유형의 문제가 많음을 알 수 있다 $\left(\chi^{2}=30.314, p=.001\right)$.

발달재활서비스 이용 아동의 연령에 따른 발달재활서비스 이용 현황을 살펴본 결과, 아동의 연령에 따라 현 지원금 적정성 여부와 적정 지원금의 차이는 없었다. 그러나 아동의 연령에 따라 치료 개 수는 유의한 차이를 보였는데 $\left(\chi^{2}=22.022, p=.001\right), 1-5$ 세가 1 개 (41.7\%)와 2개(35.9\%), 6-12세는 2개(46.6\%), 13-18세는 2개(43.6\%) 로 대부분의 연령에서 2 개 치료 프로그램을 이용하는 경우가 가장 많았다. 아동의 연령에 따라 필요한 치료 프로그램도 유의한 차이 를 보였는데 $\left(\chi^{2}=41.883, p<.001\right), 1-5$ 세와 6-12세는 각 $71.2 \%$ 와 $50.0 \%$ 의 비율로 언어치료가 가장 필요하다고 응답한 경우가 많은 반면, 13-18세는 인지/학습/행동치료(41.8\%)가 가장 필요하다고 하 였다(Table 12).

발달재활서비스 이용 아동의 연령에 따른 언어치료 발달재활서 비스 이용 현황을 분석한 결과, 연령에 따라 발달재활서비스를 이 용한 언어치료 여부, 언어치료 월평균 횟수, 언어치료 적정 월평균

Table 12. Differences in number of therapy and type of therapy most needed using Developmental Rehabilitation Service by children's age

\begin{tabular}{lccc}
\hline & \multicolumn{3}{c}{ Age group (yr) } \\
\cline { 2 - 3 } & $1-5$ & $6-12$ & $13-18$ \\
\hline Number of therapy & $43(41.7)$ & $19(16.4)$ & $11(20.0)$ \\
1 & $37(35.9)$ & $54(46.6)$ & $24(43.6)$ \\
2 & $13(12.6)$ & $26(22.4)$ & $15(27.3)$ \\
3 & $10(9.7)$ & $17(14.7)$ & $5(9.1)$ \\
$\geq 4$ & 103 & 116 & 55 \\
Total & & & \\
Type of therapy most needed & $74(71.2)$ & $58(50.0)$ & $18(32.7)$ \\
Speech-language & $12(11.5)$ & $33(28.4)$ & $23(41.8)$ \\
Intellectual/learning/behavior & $4(3.8)$ & $3(2.6)$ & $0(0)$ \\
Play & $8(7.7)$ & $7(6.0)$ & $1(1.8)$ \\
Sensory integration & $0(0)$ & $1(.9)$ & $1(1.8)$ \\
Art & $0(0)$ & $0(0)$ & $1(1.8)$ \\
Music & $3(2.9)$ & $5(4.3)$ & $5(9.1)$ \\
Psychology/counseling & $3(2.9)$ & $9(7.8)$ & $6(10.9)$ \\
Others & 104 & 116 & 55 \\
Total & &
\end{tabular}

Values are presented as number (\%). 
Jaeock Kim, et al. • Use Status and Subsidy Appropriateness of Developmental Rehabilitation Service Voucher COMMUNICATION SCIINCES \& DISORDERS

횟수 및 언어치료 자비부담 횟수와 비용은 유의한 차이가 없었다.

\section{발달재활서비스 이용 아동의 장애진단명에 따른 차이}

발달재활서비스를 이용하는 아동은 장애진단명에 따라 주된 문 제 유형의 차이를 보였는데 $\left(\chi^{2}=190.107, p<.001\right)$, 뇌병변장애는 운 동능력(67.4\%)이 주된 문제라는 응답이 가장 많은 반면, 다른 모든 장애에서는 의사소통이 주된 문제라고 응답한 경우가 가장 높은 비율을 보였다(Table 13).

발달재활서비스 이용 아동의 장애진단명에 따른 발달재활서비 스 이용 현황을 분석한 결과, 아동의 장애진단명에 따라 현 지원금 적정성 여부, 적정 지원금 및 치료 개수는 유의한 차이가 없었다. 그
러나 아동의 장애진단명에 따라 가장 필요한 치료는 유의한 차이 를 보였는데 $\left(\chi^{2}=114.802, p<.001\right)$, 뇌병변장애는 인지/학습/행동 치료(39.5\%)가 가장 많이 필요하다고 한 반면 다른 장애들은 모두 언어치료가 가장 많이 필요하다고 하였다(Table 14).

발달재활서비스 이용 아동의 장애진단명에 따른 언어치료 발달 재활서비스 이용 현황에서 아동의 장애진단명 간에 언어치료 월평 균 횟수, 언어치료 적정 월평균 횟수 및 언어치료 자비부담 횟수와 자비부담 비용은 유의한 차이가 없는 반면, 언어치료 여부는 유의 한 차이를 보였는데 $\left(\chi^{2}=45.807, p<.001\right)$, 뇌병변장애는 발달재활 서비스 지원금으로 언어치료를 제공받는다(48.8\%)와 그렇지 않다 (51.2\%)의 비율이 비슷한 반면, 다른 장애들은 모두 언어치료를 제

Table 13. Differences in name of diagnosis by type of problem

\begin{tabular}{|c|c|c|c|c|c|c|}
\hline \multirow{2}{*}{ Type of problem } & \multicolumn{6}{|c|}{ Diagnosis } \\
\hline & Autistic disorder & Intellectual disability & Communication disorder & Hearing impairment & Brain disorder & Others \\
\hline Communication & $26(68.4)$ & $53(55.8)$ & $15(72.7)$ & $5(71.4)$ & $8(18.6)$ & $5(83.3)$ \\
\hline Sociability & $6(15.8)$ & $19(20.0)$ & $2(9.1)$ & $0(0)$ & $0(0)$ & $0(0)$ \\
\hline Intellectual & $6(15.8)$ & $20(21.1)$ & $4(18.2)$ & $0(0)$ & $6(14.0)$ & $1(16.7)$ \\
\hline Hearing & $0(0)$ & $0(0)$ & $0(0)$ & $2(28.6)$ & $0(0)$ & $0(0)$ \\
\hline Motor skill & $0(0)$ & $2(2.1)$ & $0(0)$ & $0(0)$ & $29(67.4)$ & $0(0)$ \\
\hline Others & $0(0)$ & $1(1.1)$ & $0(0)$ & $0(0)$ & $0(0)$ & $0(0)$ \\
\hline Total & 38 & 95 & 22 & 7 & 43 & 6 \\
\hline
\end{tabular}

Values are presented as number (\%).

Table 14. Differences in type of therapy most needed by diagnosis

\begin{tabular}{|c|c|c|c|c|c|c|}
\hline \multirow{2}{*}{ Type of therapy most needed } & \multicolumn{6}{|c|}{ Diagnosis } \\
\hline & Autistic disorder & Intellectual disability & Communication disorder & Hearing impairment & Brain disorder & Others \\
\hline Speech-language & $19(50.0)$ & $45(47.4)$ & $18(81.8)$ & $7(100.0)$ & $5(11.6)$ & $4(66.7)$ \\
\hline Intellectual/learning/behavior & $13(34.2)$ & $31(3.2)$ & $1(4.5)$ & $0(0)$ & 17 (39.5) & $1(16.7)$ \\
\hline Play & $0(0)$ & $3(3.2)$ & $1(4.5)$ & $0(0)$ & $0(0)$ & $0(0)$ \\
\hline Sensory integration & $5(13.2)$ & $4(4.2)$ & $1(4.5)$ & $0(0)$ & $5(11.6)$ & $0(0)$ \\
\hline Art & $0(0)$ & $1(1.1)$ & $0(0)$ & $0(0)$ & $0(0)$ & $0(0)$ \\
\hline Music & $0(0)$ & $0(0)$ & $0(0)$ & $0(0)$ & $0(0)$ & $1(16.7)$ \\
\hline Psychology/counseling & $1(2.6)$ & $7(7.4)$ & $1(4.5)$ & $0(0)$ & $2(4.7)$ & $0(0)$ \\
\hline Others & $0(0)$ & $4(4.2)$ & $0(0)$ & $0(0)$ & $14(32.6)$ & $0(0)$ \\
\hline Total & 38 & 95 & 22 & 7 & 43 & 6 \\
\hline
\end{tabular}

Values are presented as number (\%).

Table 15. Differences in usage of speech-language therapy by diagnosis

\begin{tabular}{lcccccc}
\hline \multirow{2}{*}{$\begin{array}{l}\text { Usage of speech-language } \\
\text { therapy }\end{array}$} & \multicolumn{5}{c}{ Diagnosis } \\
\cline { 2 - 6 } & Autistic disorder & Intellectual disability & Communication disorder & Hearing impairment & Brain disorder & Others \\
\hline Yes & $27(97.4)$ & $83(87.4)$ & $22(100)$ & $6(85.7)$ & $21(48.8)$ & $4(66.7)$ \\
No & $1(2.6)$ & $12(12.6)$ & $0(0)$ & $1(14.3)$ & $22(51.2)$ & $2(33.3)$ \\
Total & 38 & 95 & 22 & 7 & 43 & 6 \\
\hline
\end{tabular}

Values are presented as number (\%). 
Table 16. Differences in type of therapy most needed by type of problem

\begin{tabular}{|c|c|c|c|c|c|c|}
\hline \multirow{2}{*}{ Type of therapy most needed } & \multicolumn{6}{|c|}{ Type of problem } \\
\hline & Communication & Social & Intellectual/learning & Hearing & Motor skill & Others \\
\hline Speech-language & $124(75.2)$ & $13(37.1)$ & $11(26.8)$ & $2(100.0)$ & $0(0)$ & $0(0)$ \\
\hline Intellectual/learning/behavior & $25(15.2)$ & $9(25.7)$ & $21(51.2)$ & $0(0)$ & $12(38.7)$ & $1(50.0)$ \\
\hline Play & $3(1.8)$ & $3(8.6)$ & $1(2.4)$ & $0(0)$ & $0(0)$ & $0(0)$ \\
\hline Sensory integration & $6(3.6)$ & $2(5.7)$ & $4(9.8)$ & $0(0)$ & $4(12.9)$ & $0(0)$ \\
\hline Art & $0(0)$ & $3(8.6)$ & $0(0)$ & $0(0)$ & $0(0)$ & $0(0)$ \\
\hline Music & $0(0)$ & $0(0)$ & $1(2.4)$ & $0(0)$ & $0(0)$ & $0(0)$ \\
\hline Psychology/counseling & $4(2.4)$ & $4(11.4)$ & $2(4.9)$ & $0(0)$ & $2(6.5)$ & $1(50.0)$ \\
\hline Others & $3(1.8)$ & $1(2.9)$ & $1(2.4)$ & $0(0)$ & $13(41.9)$ & $0(0)$ \\
\hline Total & 165 & 35 & 41 & 2 & 31 & 2 \\
\hline
\end{tabular}

Values are presented as number (\%).

Table 17. Differences in usage of speech-language therapy by type of problem

\begin{tabular}{lcccccc}
\hline \multirow{2}{*}{$\begin{array}{l}\text { Usage of speech-language } \\
\text { therapy }\end{array}$} & \multicolumn{5}{c}{ Type of problem } \\
\cline { 2 - 6 } & Communication & Social & Intellectual/learning & Hearing & Motor skill & Others \\
\hline Yes & $158(95.8)$ & $25(71.4)$ & $33(80.5)$ & $2(100)$ & $13(41.9)$ & $0(0)$ \\
No & $7(4.2)$ & $10(28.6)$ & $8(19.5)$ & $0(0)$ & $18(58.1)$ & $2(100)$ \\
Total & 165 & 35 & 41 & 2 & 31 & 2 \\
\hline
\end{tabular}

Values are presented as number (\%).

공받고 있다는 응답이 유의하게 더 많았다(Table 15).

\section{발달재활서비스 이용 아동의 문제 유형에 따른 차이}

발달재활서비스 이용 아동의 문제 유형에 따른 발달재활서비스 이용 현황을 분석한 결과, 아동의 장애진단명에 따라 현 지원금 적 정성 여부, 적정 지원금 및 치료 개수는 유의한 차이가 없었으나 가 장 필요한 치료는 유의한 차이를 보였는데 $\left(\chi^{2}=180.209, p<.001\right)$, Table 16 과 같이 의사소통, 사회성, 청력의 문제가 있는 경우 언어치 료를 가장 많이 필요로 하였고, 인지/학습의 문제가 있는 경우 인 지/학습/행동치료를, 운동능력의 문제가 있으면 기타(운동치료, 특 수체육 등)를 가장 많이 필요로 하였다.

발달재활서비스 이용 아동의 문제 유형에 따른 언어치료 발달재 활서비스 이용 현황을 살펴본 결과(Table 17), 언어치료 월평균 횟 수, 언어치료 월평균 적정 횟수, 언어치료 자비부담 횟수 및 비용은 유의한 차이가 없었다. 언어치료 여부만 유의한 차이를 보였는데 $\left(\chi^{2}=72.034, p<.001\right)$, 운동능력과 기타 문제가 있는 경우에는 발 달재활서비스로 언어치료를 받는다고 응답한 비율보다 그렇지 않 다고 응답한 비율이 더 높았으나 다른 문제 유형은 모두 언어치료 를 받는다는 응답이 더 많았다.

\section{발달재활서비스 이용기간에 따른 차이}

발달재활서비스 이용기간에 따른 발달재활서비스 이용 현황을
Table 18. Differences in appropriate subsidy of Developmental Rehabilitation Service voucher, number of therapy, and type of therapy most needed by period using voucher

\begin{tabular}{lcccc}
\hline & \multicolumn{5}{c}{ Period using voucher (yr) } \\
\cline { 2 - 5 } & \multicolumn{1}{c}{$\leq 1$} & $\leq 1-3$ & $\leq 3-5$ & $\geq 5$ \\
\hline Appropriate subsidy of voucher (KRW) & & & \\
Current level & $11(21.6)$ & $4(4.8)$ & $8(13.1)$ & $8(10.0)$ \\
$230,000-300,000$ & $19(37.3)$ & $36(43.4)$ & $11(18.0)$ & $14(17.5)$ \\
$310,000-400,000$ & $14(27.5)$ & $27(32.5)$ & $23(37.7)$ & $36(45.0)$ \\
$410,000-500,000$ & $5(9.8)$ & $12(14.5)$ & $10(16.4)$ & $11(13.8)$ \\
$\geq 510,000$ & $2(3.9)$ & $4(4.8)$ & $9(14.8)$ & $11(13.8)$ \\
Total & 51 & 83 & 61 & 80 \\
Number of therapy & & & & \\
1 & $22(44.0)$ & $27(32.5)$ & $13(21.3)$ & $11(13)$ \\
2 & $21(42.0)$ & $30(36.1)$ & $28(45.9)$ & $37(46.2)$ \\
3 & $5(12.0)$ & $17(20.5)$ & $11(18.0)$ & $20(25.0)$ \\
$\geq 4$ & $1(2.0)$ & $9(10.8)$ & $9(14.8)$ & $12(15.0)$ \\
Total & 50 & 83 & 61 & 80 \\
Type of therapy most needed & & & & \\
Speech-language & $35(68.6)$ & $56(67.5)$ & $32(52.9)$ & $26(32.5)$ \\
Intellectual/learning/behavior & $7(13.7)$ & $9(10.8)$ & $17(27.9)$ & $35(43.8)$ \\
Play & $4(7.8)$ & $2(2.4)$ & $1(1.6)$ & $0(0)$ \\
Sensory integration & $3(5.9)$ & $9(10.8)$ & $3(4.9)$ & $1(1.2)$ \\
Art & $0(0)$ & $2(2.4)$ & $0(0)$ & $1(1.2)$ \\
Music & $0(0)$ & $0(0)$ & $0(0)$ & $1(1.2)$ \\
Psychology/counseling & $2(3.9)$ & $3(3.6)$ & $3(4.9)$ & $5(6.2)$ \\
Others & $0(0)$ & $2(2.4)$ & $5(8.2)$ & $11(13.8)$ \\
Total & 51 & 83 & 61 & 80 \\
\hline
\end{tabular}

Values are presented as number (\%). $\mathrm{KRW}=$ Korean won. 


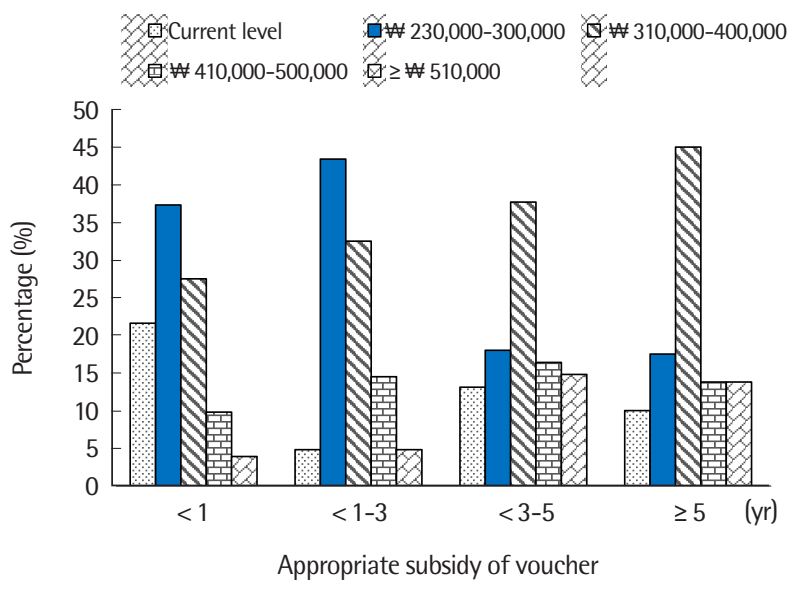

Figure 5. Appropriate subsidy of Developmental Rehabilitation Service voucher by period using voucher.

살펴본 결과, 발달재활서비스 이용기간에 따라 현 지원금 적정성 여 부는 유의한차이가 없었다. 그러나 적정 지원금 $\left(\chi^{2}=32.352, p=.001\right)$, 치료 개수 $\left(\chi^{2}=21.806, p=.010\right)$ 및 가장 필요한 치료 유형 $\left(\chi^{2}=54.771\right.$, $p<.001)$ 은 유의한 차이를 보였다. Table 18과 Figure 5에 제시된 바 와 같이 발달재활서비스를 3 년 미만으로 이용한 경우에는 발달재 활서비스 지원금으로 23-30만 원이 적정하다고 응답한 비율이 가 장 높은 반면(1년 미만 37.3\%, 1-3년 미만 43.4\%), 3년 이상 이용한 경우에는 발달재활서비스 지원금이 $31-40$ 만 원이 적정하다고 응답 한 비율이 가장 높았다(3-5년 미만 37.7\%, 5년 이상 $45.0 \%$ ). 또한 발 달재활서비스 이용기간이 1년 미만인 경우 치료를 1개(44.0\%) 또는 2 개(42.0\%)를 하는 비율이 높았지만 그 이상의 기간 동안 이용한 경우에는 2개(1-3년 36.1\%, 3-5년 미만 45.9\%, 5년 이상 46.2\%)를 하는 비율이 가장 높았다. 발달재활서비스로 가장 필요한 치료 유 형은 5년 미만까지는 언어치료의 비율이 가장 높은 반면(1년 미만 $68.6 \%, 1-3$ 년 미만 67.5\%, 3-5년 미만 52.9\%), 5년 이상이 되면서 인 지/학습/행동치료의 비율(43.8\%)이 상승하였다.

발달재활서비스 이용기간에 따른 언어치료 발달재활서비스 이 용 현황은 언어치료 여부, 언어치료 월평균 횟수, 언어치료 월평균 적정 횟수, 언어치료 자비부담 횟수 및 자비부담 비용 모두 유의한 차이를 보이지 않았다.

\section{논의 및 결론}

본 연구는 국내 발달재활서비스를 이용하는 아동의 부모를 대상 으로 발달재활서비스 지원금에 대한 인식 및 발달재활서비스 이용 현황 그리고 언어치료 발달재활서비스 이용 현황을 파악하고자 360 명의 부모에게 24 문항으로 구성된 설문조사를 실시하였고, 설
문조사에 성실하게 응답한 276 명의 자료를 이용하여 발달재활서 비스 이용 아동의 특성에 따라 발달재활서비스 이용 현황 및 언어 치료 발달재활서비스 이용 현황을 살펴보았다.

연구 결과, 설문조사에 응답한 부모들은 여성이 $88 \%$ 로 남성보다 많았고, 40 대가 가장 많았으며, 그 다음으로 30 대가 많았다. 거주지 는 인천-경기가 가장 많았고, 최종학력은 고졸부터 대학원까지 고 르게 분포되어 있었으며, 자녀 수는 2명이라고 응답한 경우가 $57 \%$ 로 가장 많았다.

발달재활서비스를 이용하는 아동의 특성에서 연령은 평균 8.16 세였고, 약 $75 \%$ 가 장애진단을 받았으며, 장애진단을 받지 않고 의 사의 진단서만으로도 발달재활서비스를 이용할 수 있는 만 5 세 이 하 아동의 장애진단 비율은 약 $42 \%$ 였다. 장애진단명으로는 지적장 애가 가장 많았으며, 1-5세는 뇌병변장애, 6-12세와 13-18세는 지적 장애가 주를 이루었는데, 이는 치료지원 바우처사업 대상 아동의 가장 많은 장애유형이 지적장애라고 밝힌 선행연구(Hwang, 2014; $\mathrm{Kim}, 2008$ )와 동일한 결과이다, 주로 보이는 문제 유형은 모든 연령 대에서 의사소통 문제가 절반 정도의 비율로 가장 많았으며, 그 다 음으로 1-5세 아동은 운동능력 문제, 6세 이후에는 인지/학습 문제 와 사회성 문제가 점차 증가하는 추세를 보여 연령에 따라 부모가 인식하는 주된 문제 유형은 차이를 보였다. 특히 학령전기인 1-5세 아동에서는 뇌병변장애가 많아 이 연령대에서는 운동능력의 문제 에 대한 인식이 높지만 학령기와 청소년기에는 지적장애로 진단 받 은 경우가 많을 뿐 아니라 이 시기에 학업에 대한 요구가 증가하는 만큼 인지/학습 관련 문제에 대한 인식이 높다고 볼 수 있다.

발달재활서비스 지원금 인식에서 발달재활서비스 지원금의 적 정성과 적정 지원금에 대한 질문에 '적정하지 않다'는 경우가 응답 자의 약 $85 \%$ 로 대부분이 적정하지 않다고 응답하였으며, $31-40$ 만 원이 가장 적정하다고 응답한 비율이 약 $60 \%$ 로 가장 높았다. 본 연 구에 참여한 기관의 발달재활서비스 언어치료 회당 단가는 32,00044,000 원으로 지역별로 차이가 있으나 전체 응답자의 다수가 발달 재활서비스 지원금이 적정하지 못하고, 응답자의 약 $90 \%$ 가 현행보 다는 발달재활서비스 지원금의 인상이 불가피하다고 응답하였다. 이는 지역별로 발달재활서비스 언어치료 회당 단가의 차이가 있다 고 하더라고 기존의 27,500 원으로 운영되던 단가에 비해서는 모두 상승한 금액으로 운영되고 있기 때문에 전반적인 정부로부터의 지 원금도 상승되어야 한다는 것이 발달재활서비스를 이용하는 아동 부모들의 인식임을 알 수 있다.

아동의 연령이나 장애진단명 또는 문제 유형에 따라서는 지원금 의 적정성이나 적정 지원금의 차이가 없었으나 발달재활서비스를 이용한 기간이 3 년 미만인 경우는 발달재활서비스 지원금으로 
23-30만 원이 적정하다고 응답한 비율이 높은 반면 3년 이상 이용 한 경우는 31-40만 원이 가장 적정하다고 응답한 비율이 높았다. 즉 발달재활서비스 이용 아동의 부모들은 발달재활서비스를 이용하 는 기간이 길수록 적정하다고 인식하는 발달재활서비스 지원금이 높아짐을 알 수 있다.

또한 발달재활서비스 이용 현황을 살펴본 영역에서 아동이 현재 제공받는 관련 치료의 개수는 2개가 가장 많았으나 연령별로 1-5 세는 1 개, 6 세 이상은 2 개가 가장 높은 비율을 보여 연령이 증가할 수록 제공받는 치료 개수가 증가하였다. 이와 더불어 발달재활서비 스 이용기간이 증가할수록 치료 개수도 증가하였는데, 이용기간이 1 년 미만은 1 개의 치료를 제공받는 비율이 높은 반면, 그 이상의 이 용기간에서는 이용기간이 증가할수록 2 개의 치료를 제공받는 비 율이 점차 증가하였다. 이것은 연령이 증가하고 발달재활서비스 이 용기간이 증가할수록 치료를 더 많이 필요로 한다는 것으로, 발달 재활서비스 이용 아동의 부모들이 적정하다고 인식하는 발달재활 서비스 지원금과도 상관성이 있는데, 연령이 많고 발달재활서비스 이용기간이 길수록 더 많은 치료를 받고 있으며 더 많은 치료가 필 요하다고 인식하기 때문에 지원금 인상의 요구가 더 있다는 것을 알 수 있다. 즉 장애유형, 장애 정도나 심각성에 따라 발달재활서비 스 지원금의 차이가 없는 국내의 현 실정을 재고해 볼 필요가 있음 을 시사한다.

아동에게 가장 필요한 치료와 현재 1 순위로 받고 있는 치료가 언 어치료로 응답한 비율과 현재 언어치료를 제공받는다고 응답한 비 율이 전 응답자의 각 $54 \%, 63 \%$, 그리고 $84 \%$ 로 발달재활서비스를 이용하는 아동은 의사소통 문제가 가장 많고 언어치료를 가장 필 요로 하며, 이는 발달재활서비스 언어치료 이용자가 각 $43.1 \%(\mathrm{Kim}$, 2008)와 68.3\% (Hwang, 2014)라고 밝힌 선행연구 결과와도 일치한 다. 즉 발달재활서비스를 이용하는 이용자들은 언어치료를 가장 많이 제공받고 있음을 알 수 있다. 하지만 13세 이후인 청소년기와 발달재활서비스 이용기간이 5년 이상인 경우에는 인지/학습/행동 치료의 비율이 점차 높아져 학령기 장애아동은 언어치료도 필요하 지만 학습 관련 중재에 대한 요구도 높음을 알 수 있다.

발달재활서비스를 이용한 월평균 언어치료 횟수는 연령, 장애진 단명, 문제 유형이나 이용기간에 상관없이 4 회가 약 $40 \%$ 로 가장 많 았다. 그러나 적정하다고 인식하는 월평균 언어치료 횟수는 8 회가 약 $50 \%$ 로 가장 많아 적정하다고 인식하는 언어치료 횟수와 실제 이용하는 치료 횟수에는 차이가 있었다. 이러한 차이는 발달재활 서비스를 이용하는 아동들이 대부분이 2 개 이상의 치료를 제공받 고 있는데, 제한된 발달재활서비스 지원금으로는 이를 충당하기 부족하여 여러 치료 프로그램의 치료 횟수를 줄여서 병행하거나
지원금 외에 추가적으로 지불하는 본인부담금 비용에 대한 부담감 때문에 이용자들은 제한된 지원금 내에서만 치료를 받으려는 경향 이 높아 실제 월평균 언어치료 횟수는 적정한 횟수에 비해 적은 것 으로 보인다. 실제로 응답자의 약 $82 \%$ 가 소득수준에 따라 지불해 야 하는 본인부담금 외에 추가로 본인부담금을 지불하고 있으며, 이 중에서도 월평균 81,000 원 이상인 경우가 약 $58 \%, 210,000$ 원 이 상은 약 $20 \%$ 로 발달재활서비스 이외에 추가적으로 지불해야 하는 비용부담이 매우 큰 것으로 조사되었다. 최근 전라남도의 4 개 도시 의 10 개 사설기관의 발달재활서비스 이용자 180 명을 대상으로 실 시한 연구(Lee, 2018)에서는 발달재활서비스 정부지원금 외 언어치 료를 위해 소요되는 본인부담금으로 5-6만 원(45.1\%)이 가장 많았 고, 그 다음으로 4 만 원(34.0\%)으로 발달재활서비스 지원금 외에 본인부담금이 많다는 것을 보여주었다. 다만 본 연구 결과와는 추 가 본인부담금액에서 차이가 있었는데, 이 선행연구는 전라남도에 한정하여 연구가 진행되었고, 본 연구에 참여한 기관 중에서도 전 라도 지역이 다른 지역에 비해 가장 낮은 회당 언어치료 단가를 보 여 발달재활서비스를 이용하는 대상자들이 정부지원금 이외에 추 가적으로 부담하는 금액이 타 지역에 비해 상대적으로 낮을 것이 라는 예측을 할 수 있다. 즉 Lee (2018)의 연구에서 제시된 추가 본 인부담금을 타 지역으로 환산하여 살펴보면 5-6만 원보다는 높은 금액을 지불하고 있다고 생각할 수 있다.

또한 언어치료를 제공받는 아동의 부모를 대상으로 언어치료 요 구 및 실태를 조사한 선행연구(Kim \& Hwang, 2013)에 의하면 부 모들이 적정하다고 인식하는 주당 언어치료 이용 회수는 2-3회로, 이를 월평균으로 계산하면 8-12회가 되며, 본 연구 결과와도 일치 한다. 2015년 실시된 연구(Kim et al., 2015)에 따르면 기관방문형 발달재활서비스 평균 치료단가가 지역별로 차이는 있지만 30,00038,000 원 정도로 현행 발달재활서비스 지원금으로 이를 지불할 때 월평균 5-6회의 치료를 제공받을 수 있다. 앞에서 언급한 바와 같이 월평균 적정한 언어치료 횟수가 8 회라고 할 때 부모들이 추가적으 로 부담해야 하는 언어치료 횟수는 2-3회 정도이며, 이를 치료단가 와 함께 고려해 보면 발달재활서비스를 이용할 때 지불해야 하는 본인부담금 외에 추가적으로 부담해야 하는 본인부담금비용은 최 소 80,000 원 이상이 된다는 것을 알 수 있으며, 이는 본 연구 결과에 서 제시된 월평균 81,000 원 이상의 본인부담금비용을 지불하는 경 우가 많다는 것과도 일맥 상통한다.

끝으로 응답자의 약 $94 \%$ 에서 아동이 성인이 된 후에도 정부로부 터의 치료지원금이 필요하다고 응답하여 현재 0-18세로 제한되어 있는 발달재활서비스 지원 대상이 성인으로까지 확대되어야 할 필 요가 있음을 시사한다. 
Jaeock Kim, et al. • Use Status and Subsidy Appropriateness of Developmental Rehabilitation Service Voucher

발달재활서비스 이용 아동의 부모를 대상으로 발달재활서비스 이용 현황과 지원금에 관한 인식을 조사한 본 연구 결과를 종합해 보면, 부모들이 적정하다고 인식하는 발달재활서비스 지원금은 $310,000-400,000$ 원이었으며, 적정 월평균 언어치료 횟수는 8 회로 언어재활사를 대상으로 한 연구 보고와 일치하였다(Kim, Jung, $\mathrm{Kim}, \& \mathrm{Lee}, 2018)$. 부모들은 장애아동들에게 가장 필요한 치료가 언어치료이며 월평균 최소 8 회를 실시해야 하는데, 현재 지원되는 발달재활서비스 지원금으로는 1 개의 치료를 이용하기에도 부족하 며, 아동 1 명당 최소 2 개 이상의 치료가 요구되는데, 이를 위해 1 개 의 치료 당 발달재활서비스의 횟수를 줄이고 각 개인의 요구에 필 요한 다양한 치료를 실시하고 있음을 알 수 있었다. 이는 부모의 다 양한 요구와 필요에 비해 턱없이 부족한 발달재활서비스 지원금으 로 인한 결과로 보여진다. 장애아동에게 다양한 측면의 치료를 함 께 제공하는 것도 필요하지만 적절한 치료를 충분히 제공해 주는 것 또한 필요하다. 그러나 장애아동의 치료지원을 위해 마련된 현 행 발달재활서비스 지원금으로는 이를 만족시키지 못하고 있으며, 1 개의 치료라도 적절하게 제공되기 위해서는 지원금의 인상이 불 가피하다고 보여진다.

본 연구는 일부 지역에 한정하여 조사한 내용으로 추후 전국의 발달재활서비스 제공기관에서 재활치료서비스를 제공받는 부모 를 대상으로 조사가 이루어진다면 지원금의 적정성, 지역별 발달재 활서비스 현황 및 언어치료 발달재활서비스 현황 등에 대한 좀 더 자세한 비교가 이루어질 수 있을 것이다. 또한 다양한 재활치료서 비스 유형별로 구분하여 치료단가, 치료횟수 등을 파악하여 비교 한다면 현 발달재활서비스 이용 현황에 대한 자세한 정보를 얻을 수 있을 것이다.

\section{REFERENCES}

Association of Korea Speech-Language Pathology. (2015). Whole investigation on national speech-language pathology. http://www.kslp.org.

Chung, M., \& Seo, J. E. (2010). A study on the states and demands for desire of the Rehabilitation Service by property of handicapped children: focused on the children who received a benefit of Vouchers work. Korean Journal of Family Welfare, 15, 157-173.

Han, C. G., \& Hwang, S. S. (2012). Professionalism perception of speech and language pathologists in Korea. Journal of Speech-Language \& Hearing Disorders, 21, 287-305.

Hwang. J. (2014). Influence on consumer satisfaction by factors of rehabilitation services developing children with disabilities: cases in Gyeonsanbuk Prov- ince (Master's thesis). Kyungpook University, Daegu, Korea.

Hwang, J. H. (2016). Future directions in vocational rehabilitation policy for people with developmental disabilities: focusing on the recent U.S. policy changes. Journal of Disability and Welfare, 34, 65-92.

Jeon, H. (2016). Home and community based services (HCDBS) for intellectual and developmental disabilities. http://www.ablenews.co.kr/News/NewsContent.aspx?CategoryCode $=0022 \&$ NewsCode $=002220160620110550422372$.

Kang, J. B., \& Cho, J. M. (2014). A study on improvement of developmental rehabilitation service. Journal of Special Education \& Rehabilitation Science, 53, 91-116.

Kang, M. H., Kim, J. H., \& Park, J. H. (2011). A study on the improvement of accessibility of rehabilitation therapy for children with disabilities. Seoul: Korea Disabled People's Development Institute.

Kim, J., Cho, Y., Park, J., \& Lee, E. (2014). Present status and improvement direction of Developmental Rehabilitation Services based on service and personnel of service providing centers. The Journal of Developmental Disabilities, 18, 1-23.

Kim, J., Jung, K., Kim, T., \& Lee, J. (2018). Report on unit cost of Developmental Rehabilitation Service. Seoul: Association of Korea Speech-Language Pathology.

Kim, J. H., \& Hwang, S. S. (2013). Parents' practices and demands in speech therapy service delivery by age groups. Journal of Speech-Language \& Hearing Disorders, 22, 273-297.

Kim, J. H., Kim, K. R., \& Kang, J. B. (2015). A study on supporting status and improvement of Rehabilitation Service for children with disabilities. Journal of Emotional \& Behavioral Disorders, 31, 251-281.

Kim, S. (2008). Present status and desires of the participants in the Voucher program for therapy and rehabilitation. Korean Journal of Communication Disorders, 13, 691-706.

Lee, E. S. (2018). A study on satisfaction and experience of parents of disabled children using the language therapy voucher service (Master's thesis). Chonnam University, Gwangju, Korea.

Lee, S. (2010). Voucher rehabilitation services for children with disabilities satisfaction study: Featured in the center area of Gyeonggi Province (Master's thesis). Kangnam University, Yongin, Korea.

Lee, Y. (2009). A qualitative study on speech therapy voucher service for disabled children's parents (Master's thesis). Daegu University, Daegu, Korea.

Ministry of Health and Welfare. (2010). Survey on the actual conditions of the private therapy institutions for the disabled children. Seoul: Author.

Moon, J. (2015). Improvement direction of Developmental Rehabilitation 
Services. The Journal of Developmental Disabilities, 19, 1-23.

Oh, H., Yang, S. \& Jeon, H. (2009). Survey on the use of rehabilitation treatment for children with disabilities and improvement plan. Seoul: Korea Disabled People’s Development Institute.

Park, D. S. (2014). The factors affecting parental satisfaction with the use of the voucher service for Disabled Children's Development Rehabilitation (Master's thesis). Dongguk University, Seoul, Korea.
Park, H., Lee, M. S., \& Park, C. H. (2013). Job stress factors and turnover of registered Voucher language pathologists. Journal of Speech-Language \& Hearing Disorders, 22, 227-250.

Social Security Information Service. (2013). Status of Developmental Rehabilitation Services. http://www.isis.or.kr.

Social Security Information Service. (2015). Status of Developmental Rehabilitation Services. http://www.isis.or.kr. 
Jaeock Kim, et al. • Use Status and Subsidy Appropriateness of Developmental Rehabilitation Service Voucher COMmuniCATION SCIENCES\& DISORDERS

Appendix 1. 언어치료 발달재활서비스 이용 현황 및 지원금 적정성

안녕하십니까?

본 설문 조사는 (사)한국언어재활사협회에서 진행하는 '2018년 발달재활서비스 단가 실태조사' 용역연구의 일환으로, 발달재활서비스의 이용 현황 및 지원금

의 적정성 여부를 조사함으로써 추후 발달재활서비스의 질적 향상을 위한 개선방안을 모색하고자 하는 데 목적을 두고 있습니다.

본 설문에 응답하신 의견은 연구를 위한 목적으로만 사용하며, 개인정보 및 응답사항은 통계법 제33조(비밀의 보호)와 제34조(통계 작성 사무종사자 등의 의 무)에 의해 비밀이 보장되며, 오직 통계목적을 위해서만 사용하도록 할 것입니다.

단, 본 설문지를 작성함에 있어 발달재활서비스를 제공받는 자녀가 2 명 이상일 경우에는 번거로우시더라도 해당 자녀의 수만큼 설문지를 따로 기재해 주시면 감사 드리겠습니다.

감사합니다.

\section{〈기본정보〉}

1. 귀하의 성별은?
(1) 남
(2) 여

2. 귀하의 연령은? (만 나이)
(1) 20 29세
(2) 30 39세
(3) 40 49세
(4) 50 59세
(5) 60 세 이상

3. 귀하의 최종학력은?
(1) 고졸 이하
(2) 전문대졸
(3) 대졸
(4) 대학원 이상

4. 현재 거주하고 계신 지역을 선택해 주세요.
(1) 서울
(2) 인천-경기
(3) 광주-전라
(4) 대구-경북
(5) 부산-울산-경남 (6) 강원
(7) 기타 (
)

5. 귀하의 자녀는 몇 명입니까?
(1) 1 명
(2) 2 명
(3) 3 명
(4) 4 명
(5) 5 명 이상

6. 현재 발달재활서비스를 제공받고 있는 아동의 연령은? (만 나이)

(세)

7. 현재 발달재활서비스를 제공받고 있는 자녀는 장애 진단을 받았습니까?
(1) 예
(2) 아니오

8. 7번 문항에 "예"라고 답한 경우, 귀하의 자녀가 받은 장애 진단명은? (중복응답 가능)
(1) 자폐성장애
(2) 지적장애
(3) 언어장애
(4) 청각장애
(5) 뇌병변장애
(6) 기타

9. 현재 자녀는 주로 어떤 부분의 어려움으로 발달재활서비스를 제공받고 있습니까? (중복응답 가능)
(1) 의사소통
(2) 사회성
(3) 인지
(4) 청력
(5) 운동능력
(6) 기타 
10. 발달재활서비스를 이용한 총 기간은?
(1) 1 년 미만
(2) 1 2년 미만
(3) 2 3년 미만
(4) 3 4년 미만
(5) 4 5년 미만
(6) 5 6년 미만
(7) 6 7년 미만
(8) 7 년 이상

11. 현재 이용하고 있는 발달재활서비스 지원금(22만 원/월)이 적정하다고 생각하십니까?
(1) 예
(2) 아니오

12. 발달재활서비스 월 지원금은 얼마가 적정하다고 생각하십니까?
(1) 현재 수준
(2) 23 30만 원
(3) $31 \sim 40$ 만 원
(4) $41 ~ 50$ 만 원
(5) 51 만 원 이상

13. 현재 자녀가 치료를 받고 있는 발달재활서비스 및 일반 비용 부담 프로그램의 총 개수는? (예, 언어치료, 놀이치료, 미술치료를 하고 있다면 3개)
(1) 1 개
(2) 2 개
(3) 3 개
(4) 4 개 이상

14. 현재 자녀에게 가장 필요하다고 생각하는 발달재활서비스 프로그램은 무엇입니까?
(1) 언어치료
(2) 인지/학습/행동치료
(3) 놀이치료
(4) 감각통합
(5) 미술치료
(6) 음악치료
(7) 심리/상담치료
(8) 기타 (

15. 현재 자녀가 1 순위로 제공받는 발달재활서비스 프로그램은 무엇입니까?
(1) 언어치료
(2) 인지/학습/행동치료
(3) 놀이치료
(4) 감각통합
(5) 미술치료
(6) 음악치료
(7) 심리/상담치료
(8) 기타 (

16. 현재 자녀가 2 순위로 제공받는 발달재활서비스 프로그램은 무엇입니까?
(1) 언어치료
(2) 인지/학습/행동치료
(3) 놀이치료
(4) 감각통합
(5) 미술치료
(6) 음악치료
(7) 심리/상담치료
(8) 기타 (

17. 현재 자녀가 발달재활서비스 지원금으로 언어치료를 제공받고 있습니까?
(1) 예
(2) 아니오

18. 현재 자녀가 발달재활서비스 지원금으로 제공받는 월 평균 언어치료 횟수는?
(1) 4회 미만
(2) 4회
(3) 5 회
(4) 6 회
(5) 7회
(6) 8회
(7) 9 회 이상

19. 현재 자녀가 발달재활서비스 지원금으로 제공받는 언어치료는 월 평균 몇 회가 적정하다고 생각하십니까?
(1) 4회 미만
(2) 4 회
(3) 5 회
(4) 6 회
(5) 7회
(6) 8회
(7) 9 회 이상

20. 현재 자녀가 발달재활서비스 지원금으로 언어치료를 제공받을 때 본인부담금(정부 지정 금액)은 얼마입니까?
(1) 없음(면제)
(2) 2 만 원
(3) 4 만 원
(4) 6 만 원
(5) 8 만 원

21. 현재 자녀가 발달재활서비스 지원금으로 언어치료를 제공받을 때 본인부담금 금액이 적정하다고 생각하십니까?
(1)예
(2) 아니오

22. 현재 자녀가 발달재활서비스 지원금(본인부담금 포함) 외에 자비로 추가 부담하여 치료받는 월 평균 언어치료 횟수는?
(1) 없음
(2) 1 회
(3) 2회
(4) 3 회
(5) 4회
(6) 5 회 이상

23. 현재 자녀가 발달재활서비스 지원금 외에 자비로 부담하는 월 평균 언어치료 비용은? (정부 지정 본인부담금은 제외)
(1) 없음
(2) 40,000 원 이하
(3) $41,000 \sim 80,000$ 원
(4) $81,000 ~ 120,000$ 원
(5) $121,000 ~ 160,000$ 원
(6) $161,000 ~ 200,000$ 원
(7) 210,000 원 이상

24. 자녀가 성인이 되어서도 발달재활서비스와 같은 치료지원 지원금이 지속적으로 필요하다고 생각하십니까?
(1)예
(2) 아니오

수고해 주심에 감사 드립니다. 
Jaeock Kim, et al. • Use Status and Subsidy Appropriateness of Developmental Rehabilitation Service Voucher

\section{국문초록}

\section{언어치료를 위한 발달재활서비스 이용 현황 및 지원금의 적정성 연구: 부모를 대상으로}

김재옥'(교수, 제1저자, 교신저자) · 김태우(연구소장) · 이조영(센터장, 언어치료사) · 정경희'(교수)

강남대학교 교육대학원 언어치료교육전공, ${ }^{2}$ 김태우심리언어연구소, ${ }^{3}$ 리엔리언어심리학습센터, ${ }^{4}$ 용인대학교 재활복지대학원 언어치료학과

배경 및 목적: 발달재활서비스 지원금은 물가나 최저임금 등의 상승을 고려하지 않은 채 10 여 년이 지난 현재까지 동일하게 유지되고 있 어 질 높은 재활치료서비스를 제공하지 못하고 있다. 이에 본 연구는 발달재활서비스를 이용하는 아동의 부모를 대상으로 국내 발달재 활서비스 지원금에 대한 인식 및 발달재활서비스 이용 현황, 특히 언어치료서비스의 이용 현황에 대한 인식을 조사하고자 하였다. 방법: 발달재활서비스를 이용하는 아동의 부모를 대상으로 발달재활서비스 지원금 인식, 발달재활서비스 이용 현황과 언어치료 발달재활서 비스 이용 현황에 관한 24 문항으로 구성된 설문지를 배부하고 성실하게 응답된 276 부의 자료를 분석하였다. 결과: 발달재활서비스 현 황에서 현행 발달재활서비스 지원금이 적정하지 않다고 응답한 비율이 $85 \%$ 였고, 31-40만 원이 가장 적정한 지원금이라고 응답한 비율 이 가장 높았으며, 발달재활서비스 이용기간이 길수록 적정하다고 인식하는 발달재활서비스 지원금의 액수가 높아졌다. 아동이 현재 발달재활서비스로 제공받는 치료의 개수는 2 개가 가장 많았으며, 가장 필요하고 가장 많이 이용하는 치료 유형은 언어치료였다. 발달재 활서비스를 이용한 월평균 언어치료 횟수는 4 회가 가장 많았으나 적정하다고 인식하는 언어치료 횟수는 8 회가 가장 많았다. 발달재활 서비스 지원금 외 추가로 부담하는 자부담금은 응답자의 약 $74 \%$ 가 80,000 원 이상을 지불한다고 하였다. 또한 응답자의 약 $94 \%$ 가 아동 이 성인이 된 후에도 정부로부터의 치료지원금이 필요하다고 하였다. 논의 및 결론: 장애아동의 치료지원을 위해 마련된 발달재활서비 스는 현행 제공되는 지원금이 이용 아동의 부모들이 인식하기에 충분하지 않으며 지원금의 인상이 반드시 필요하다고 보여진다.

핵심어: 발달재활서비스, 지원금의 적정성, 부모 설문조사

본 논문은 (사)한국언어재활사협회의 '2018발달재활서비스 단가 실태조사’에 관한 외부연구용역의 일부로 진행된 연구임.

\section{참고문헌}

강민희, 김지혜, 박지혜(2011). 장애아동 재활치료 이용의 접근성 향상에 관한 연구. 서울: 한국장애인개발원. 강정배, 조정민(2014). 발달재활서비스 제도개선 방안에 관한 연구. 특수교육재활과학연구, 53, 91-116. 김수진(2008). 치료지원 바우처사업 대상아동의 장애유형과 연령에 따른 재활치료 실태 및 부모욕구조사. 언어청각장애연구, 13, 691-706. 김재옥, 정경희, 김태우, 이조영(2018). 발달재활서비스 단가 실태 조사에 관한 외부연구용역 과제 최종보고서. 서울: 한국언어재활사협회. 김정희, 김경란, 강정배(2015). 장애아동 재활서비스 지원 사업 실태 및 개선방안. 정서행동장애연구, 31, 251-281.

김정희, 조윤경, 박주영, 이의정(2014). 발달재활서비스 제공기관의 서비스 및 인력 현황과 개선방안. 발달장애연구, 18, 1-23.

김지현, 황상심(2013). 자녀 연령에 따른 장애아 부모의 언어치료 실태 및 요구 조사. 언어치료연구, 22, 273-297.

문장원(2015). 발달재활서비스의 현황과 개선방안. 발달장애연구, 19, 1-23.

박대삼(2014). 장애아동 발달재활치료 바우처 서비스 이용에 대한 부모 만족도에 미치는 영향요인. 동국대학교 대학원 석사학위논문.

박현, 이명순, 박찬희(2013). 바우처 언어재활사의 직무스트레스 요인과 이직의도. 언어치료연구, 22, 227-250.

보건복지부(2010). 장애아동사설치료기관 실태조사. 서울: 보건복지부.

사회보장정보원(2013). 발달재활서비스 현황. http://www.ssis.or.kr.

사회보장정보원(2015). 발달재활서비스 현황. http://www.ssis.or.kr.

오혜경, 양숙미, 전혜연(2009). 장애아동재활치료 이용 실태조사 및 개선방안. 서울: 한국장애인개발원.

이수경(2010). 장애아동재활치료 바우처 서비스 만족도에 관한 연구. 강남대학교 대학원 석사학위논문.

이영선(2009). 장애아동 부모의 언어치료 바우처 서비스 이용에 관한 질적사례연구. 대구대학교 대학원 석사학위논문. 
이은선(2018). 언어치료 바우처 서비스를 이용하는 장애아동 부모의 만족도와 경험에 관한 연구. 전남대학교 대학원 석사학위논문.

전현일(2016). 미국의 발달장애인을 위한 가정, 지역사회 근거한 서비스. http://www.ablenews.co.kr/News/NewsContent.aspx?CategoryCode $=002$ 2\&NewsCode $=002220160620110550422372$.

정민정, 서주은(2010). 장애아동 특성에 따른 재활치료 서비스 현황 및 욕구조사에 관한 연구: 바우처 사업 수혜자를 중심으로. 한국가족복지학, 15, $157-173$.

한국언어재활사협회(2015). 국가자격 언어재활사 대상 전수조사. http://www.kslp.org. 한춘근, 황상심(2012). 바우처 기관 언어치료사의 직업 전문성 인식에 관한 연구. 언어치료연구, 21, 287-305. 황재준(2014). 장애아동 발달재활서비스 요인이 이용만족도에 미치는 영향. 경북대학교 대학원 석사학위논문.

황주희(2016). 발달장애인 직업재활정책의 방향 모색: 미국의 발달장애인 지원정책의 변화를 중심으로. 한국장애인복지학, 34, 65-92. 